\title{
Health effects of protein intake in healthy elderly populations: a systematic literature review
}

\author{
Agnes N. Pedersen ${ }^{1 *}$ and Tommy Cederholm² \\ 'DTU Food, National Food Institute, Søborg, Denmark; ${ }^{2}$ Department of Public Health and Caring Sciences, Uppsala \\ University, Uppsala, Sweden
}

\begin{abstract}
The purpose of this systematic review is to assess the evidence behind the dietary requirement of protein and to assess the health effects of varying protein intake in healthy elderly persons in order to evaluate the evidence for an optimal protein intake. The literature search covered year 2000-2011. Prospective cohort, case-control, and intervention studies of a general healthy population in settings similar to the Nordic countries with protein intake from food-based sources were included. Out of a total of 301 abstracts, 152 full papers were identified as potentially relevant. After careful scrutiny, 23 papers were quality graded as A (highest, $n=1), \mathrm{B}(n=18)$, or $\mathrm{C}(n=4)$. The grade of evidence was classified as convincing, probable, suggestive, or inconclusive. The evidence is assessed as: probable for an estimated average requirement (EAR) of $0.66 \mathrm{~g}$ good-quality protein $/ \mathrm{kg}$ body weight $(\mathrm{BW}) /$ day based on nitrogen balance (N-balance) studies and the subsequent recommended dietary allowance (RDA) of $0.83 \mathrm{~g}$ good-quality protein $/ \mathrm{kg} \mathrm{BW} / \mathrm{day}$ representing the minimum dietary protein needs of virtually all healthy elderly persons. Regarding the optimal level of protein related to functional outcomes like maintenance of bone mass, muscle mass, and strength, as well as for morbidity and mortality, the evidence is ranging from suggestive to inconclusive. Results from particularly prospective cohort studies suggest a safe intake of up to at least $1.2-1.5 \mathrm{~g}$ protein $/ \mathrm{kg}$ BW/day or approximately 15-20 E\%. Overall, many of the included prospective cohort studies were difficult to fully evaluate since results mainly were obtained by food frequency questionnaires that were flawed by underreported intakes, although some studies were 'calibrated' to correct for under- or over-reporting. In conclusion, the evidence is assessed as probable regarding the EAR based on N-balance studies and suggestive to inconclusive regarding an optimal protein intake higher than the estimated RDA assessed from N-balance studies, but an exact level cannot be determined. Potentially adverse effects of a protein intake exceeding $20-23 \mathrm{E} \%$ remain to be investigated.
\end{abstract}

Keywords: protein requirements; nitrogen balance; old age; mortality; chronic disease; sarcopenia; Nordic nutrition recommendations

Received: I3 November 20 I3; Revised: I3 November 20 I3; Accepted: I3 November 20 3; Published: II February 20 I4

$\mathrm{T}$ he present literature review is part of the fifth version of the Nordic Nutrition Recommendations (NNR5) project with the aim of reviewing and updating the scientific basis of the fourth edition of the NNR issued in 2004 (1). The NNR5 project is mainly focused on a revision of those areas in which new scientific knowledge has emerged since the fourth edition, with special relevance for the Nordic setting. A number of systematic literature reviews form the basis for establishment of dietary reference values in NNR5. The present expert group was established to systematically review studies regarding nitrogen balance (N-balance) and protein quantity and sources (animal versus vegetable) associated with health outcomes among healthy elderly populations.

In 2002, the Institute of Medicine (IoM) published the US dietary reference values for protein (2) that was mainly based on a meta-analysis of $\mathrm{N}$-balance studies by Rand et al. (3) to estimate protein requirement. This meta-analysis included only one study that reported individual data on protein requirements of older subjects (4). They reported no statistically significant variations by adult age or sex.

The meta-analysis by Rand et al. was also taken into account in the NNR4 protein requirement assessment. While the US recommendation was expressed as $0.83 \mathrm{~g}$ 
good-quality protein/kg body weight $(\mathrm{BW}) /$ day, the NNR4 recommendation was given as 10-20 energy percent $(\mathrm{E} \%)$ from protein, which allowed for an overall macronutrient intake distribution, as well as adaptation to the Nordic dietary habits. The Nordic recommended protein intake of $10-20 \mathrm{E} \%$ was considered adequate to meet the requirement for protein, including essential amino acids for healthy elderly persons too.

In 2007, the WHO/FAO/UNU published their most recent recommendation on protein requirement (5), which was also based on the Rand et al. meta-analysis (3), but with increased requirements for most essential amino acids, which made a certain level of protein quality necessary. In 2012, the European Food Safety Authority (EFSA) published their Dietary Reference Values for protein based on $\mathrm{N}$-balance studies (6), again mainly the Rand meta-analysis (3). These recommendations were the same for the healthy elderly as for the general populations. Both the WHO and the EFSA Panel considered several health outcomes associated with protein intake, but data were found to be insufficient to establish Dietary Reference Values.

Thus, until now, recommendations on protein requirements have been based on N-balance studies only. The recommendations of an optimal protein intake in relation to health outcomes are not clear. The present evidence on the relationship between protein intake and health outcomes has, however, not been based on systematic literature reviews.

The purpose of this systematic review was to re-assess the evidence for the dietary requirement of protein based on N-balance studies, and to assess the health effects of varying protein intake in healthy elderly populations based on prospective observational cohort or casecontrol studies and randomized controlled studies.

\section{Methods}

The process for conducting the systematic review is described in detail in the guidelines devised by the NNR5 working group (7). Briefly, the key characteristics of the systematic review are

1) Definition of the research questions to be answered.

2) Definition of the eligibility criteria.

3) A systematic search that attempts to identify all studies that would meet the eligibility criteria.

4) A systematic selection and evaluation of the included papers.

5) Construction of summary tables of the studies.

6) Rating the evidence and formulate conclusions.

\section{Research questions}

The main protein expert group for the adult population made the research questions in cooperation with other relevant expert groups including the Elderly Group, see Appendix 1.

\section{Eligibility criteria}

We included studies reporting protein intake from foods, but excluded studies using isolated protein as supplements, as well as studies based on the intake of certain amino acids.

Population

Studies of general healthy elderly populations with a mean age of $\geq 65$ years in settings similar to the Nordic countries were included, while studies with disabled/frail elderly were excluded. But since the review deals with elderly people, the described studies are likely to include people with various health problems such as sarcopenia, cardiovascular risk factors like hypertension and dyslipidemia, or some diseases that did not hinder free-living. Studies without Caucasians or with Caucasians as a minority group were excluded. Secondary prevention studies, studies that addressed adiposity or obesity, and studies on athletes were also excluded.

Study type and design

Observational studies: prospective cohort studies and case-control studies were included, while cross-sectional studies were excluded. Studies were also excluded if length of follow-up was obviously too short to reliably assess the stated outcome. No studies with less than 1-year follow-up were included.

For controlled intervention studies, the required length of study depended on outcome; for N-balance studies the length was set to at least 14 days in accordance with a recent meta-analysis (3). Single meal postprandial studies were excluded. Required number of participants depended on outcome and power calculations.

Publication language had to be English or any of the Nordic languages.

\section{Publication type}

Original articles, meta-analyses, and systematic reviews were included. Narrative reviews were examined to ensure that all relevant studies were included.

Time period for publication

2000 onward.

\section{Search method and terms}

The protein expert group that addressed the adult population defined the search terms relevant for both adults and the elderly in collaboration with a librarian, see Appendix 2. The databases used were PubMed and SweMed (the latter was used to identify Nordic papers not published in PubMed). The main search included the period January 2000 to January 2011. An additional 
search was run in Medline through the PubMed platform in January 2012 in order to update the search with the most recent papers published from January to December 2011.

\section{Selection and evaluation of papers}

Screening of all the papers was carried out by the two authors. The first screening included 301 abstracts sent from the main protein group. All articles suggested by at least one of the two experts were ordered as full text papers. The second screening included 152 full text papers, and papers suggested by at least one expert were included in the quality assessment. The quality assessment was done according to the principles in the guidelines (7). Briefly, a quality assessment tool specific for the study type was used to grade the papers as $\mathrm{A}=$ high quality study with very low level of potential bias; $\mathrm{B}=$ some bias, but not enough to invalidate the results; $\mathrm{C}=$ significant bias and weaknesses that may invalidate the results. Then, after the quality grading, evidence tables were constructed with a description and the quality assessment of each study. Finally, for each evaluated outcome with more than one article, the grading of evidence was based on summary tables and a four-class grading: convincing (high), probable (moderate), suggestive (low), and inconclusive (insufficient). The minimum requirement for suggestive was two studies showing an association, and no conflicting results. If some studies showed a nonsignificant (neither positive nor negative) association, it was decided that for suggestive evidence the number of studies showing an association was required to be at least two higher than those showing no association.

\section{Results}

The total search included 301 abstracts. The initial main search included 267 abstracts screened for eligibility (Fig. 1). Of these, 137 were selected and ordered as full text papers, including narrative reviews. The additional search (January-December 2011) resulted in 34 abstracts of which 15 were ordered as full text papers, including narrative reviews. Thus, 152 full text papers were included in the second screening.

A total of 23 papers were quality graded, including two additional papers identified through reference lists from the included papers and the narrative reviews (Fig. 1).

The reasons for exclusion of the 131 full text papers are shown in Appendix 3.

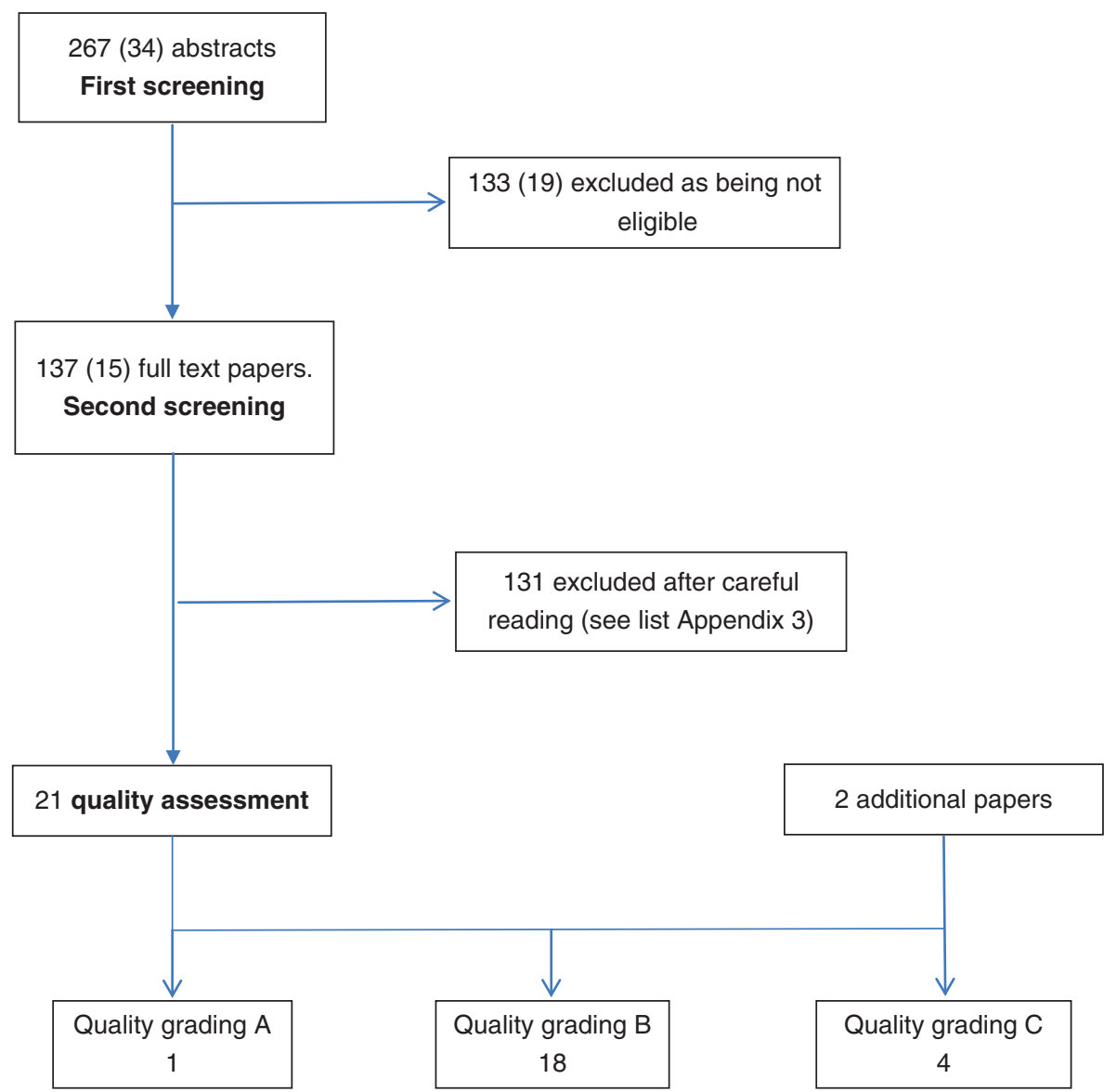

Fig. 1. Flow-chart of the systematic literature review process. Numbers in brackets are the additional searches in 2011. 
Dietary requirement of protein based on $N$-balance studies The studies used for the grading of evidence for protein requirements based on $\mathrm{N}$-balance studies are one metaanalysis including $19 \mathrm{~N}$-balance studies (3), quality graded as B, and four controlled metabolic studies (8-11), quality graded as B, A, B, and B, respectively, see Appendix 4, Table 1.

Rand et al.'s meta-analysis from 2003 (3) included 19 N-balance studies of eucaloric diets with at least three test protein intakes given. Only one study (4) in the meta-analysis reported individual data on requirements of older subjects. The meta-analysis found no significant differences in requirements between adult age, sex, or source of dietary protein, but they also stated that the data did not provide sufficient power to detect possible differences. The median estimated nitrogen requirement was $105 \mathrm{mg} \mathrm{N} / \mathrm{kg} \mathrm{BW/day} \mathrm{corresponding} \mathrm{to} 0.66 \mathrm{~g}$ goodquality protein/kg BW/day, and based on the 97.5 th percentile, the estimated recommended dietary allowance (RDA) was set to $0.83 \mathrm{~g}$ good-quality protein $/ \mathrm{kg} \mathrm{BW} /$ day.

In 2001, Campbell et al. (8) conducted a small 14-week strictly controlled metabolic study with 10 healthy elderly men and women who were provided $0.8 \mathrm{~g}$ protein $/ \mathrm{kg}$ BW in a eucaloric diet. There was no young control group. Steady state was reached at week 2 indicating that the protein intake was adequate for the participants. But hereafter the urinary nitrogen excretion decreased and was associated with a loss in mid-thigh muscle area. The authors suggested that the protein intake might have been marginally inadequate and result in longer-term accommodation in skeleton muscle.

In a controlled metabolic study by Morse et al. (10), 11 healthy elderly women were provided diets with three different protein intake levels, that is, low protein diet: $0.5 \mathrm{~g} / \mathrm{kg} \mathrm{BW}$; medium: $0.75 \mathrm{~g} / \mathrm{kg}$ BW; high: $1.0 \mathrm{~g} / \mathrm{kg}$ BW during three 18-day periods with a minimum 1-week habitual diet between the periods. N-balance was determined at week 2 and 3 of each diet. Mean adequate protein allowance was estimated to be $0.90 \mathrm{~g} / \mathrm{kg} \mathrm{BW}$ at week 2 and $0.76 \mathrm{~g} / \mathrm{kg} \mathrm{BW}$ at week 3 , but the urinary nitrogen excretion decreased between week 2 and 3 indicating that a steady state was not reached yet.

In 2008, Campbell et al. (9) tested young versus old, and men versus women in a high quality controlled metabolic study with a low protein $(0.5 \mathrm{~g} / \mathrm{kg} \mathrm{BW})$, medium protein $(0.75 \mathrm{~g} / \mathrm{kg} \mathrm{BW})$ and high protein (HP) $(1.0 \mathrm{~g} / \mathrm{kg} \mathrm{BW})$ diet. The included elderly women were apparently the same as in the study by Morse et al. (10). After 18 days, the N-balance was not different between the four groups, and the estimated requirement expressed per $\mathrm{kg}$ BW was not significantly different for the young versus old, or men versus women. Mean protein requirement was lower for older women versus older men, but expressed per $\mathrm{kg}$ fat-free mass (FFM) there was no significant difference. For all subjects combined, the adequate protein allowance was estimated to be $0.85 \pm$ $0.21 \mathrm{~g} / \mathrm{kg} \mathrm{BW} /$ day, and not statistically different from the estimate of $0.83 \mathrm{~g} / \mathrm{kg} \mathrm{BW} /$ day, as suggested by Rand et al. (3).

A short-term study was also included because of an HP intake in the test meal versus usual protein (UP) intake (11). Young men and women (UP $1.04 \mathrm{~g} / \mathrm{kg} \mathrm{BW}$ and HP $2.08 \mathrm{~g} / \mathrm{kg} \mathrm{BW}$ ) versus old men and women (UP $0.89 \mathrm{~g} / \mathrm{kg}$ $\mathrm{BW}$ and HP $1.79 \mathrm{~g} / \mathrm{kg} \mathrm{BW}$ ) were tested for 10 days on each diet in a cross-over design. There was no age related difference in N-balance. Still, there was concern about an $\mathrm{HP}$ diet corresponding to ca. $24 \mathrm{E} \%$ in the elderly because of a potentially negative effect on the kidney function expressed as lack of increase in glomerular filtration rate (GFR) from a habitual low GFR value among the elderly participants.

In summary, the evidence is assessed as probable regarding the estimated average requirement (EAR) of $0.66 \mathrm{~g}$ good-quality protein $/ \mathrm{kg} \mathrm{BW}$ per day and the subsequent RDA of $0.83 \mathrm{~g}$ good-quality protein $/ \mathrm{kg} \mathrm{BW}$ per day for all adult age groups, including the elderly, based on N-balance studies (Table 1).

The evidence of potential adverse effects of a HP diet (ca. $24 \mathrm{E} \%$ ) based on only one study is regarded as inconclusive (Table 1).

\section{Protein intake and muscle mass}

The evaluation of the association between protein intake and muscle mass among healthy elderly persons is based on one randomized controlled trial (12), quality graded as B, and two prospective cohort studies $(13,14)$, quality graded as B and C, respectively, see Appendix 4, Table 2.

In a small study with 12 healthy elderly women, Castaneda et al. (12) provided two weight-maintaining diets with marginal protein $(0.45 \mathrm{~g} / \mathrm{kg} \mathrm{BW})$ and adequate protein $(0.92 \mathrm{~g} / \mathrm{kg} \mathrm{BW})$, respectively. This corresponded to an estimated protein $\mathrm{E} \%$ of ca. $6 \mathrm{E} \%$ and $13 \mathrm{E} \%$, respectively. After 10 weeks, the women with the marginal protein intake had statistically significant decreased muscle mass from $17 \pm 0.9$ to $14.7 \pm 0.8 \mathrm{~kg}$, and decreased muscle fiber cross-sectional area (CSA) (type I fibers) as well as a decrease in the protein-sensitive anabolic mediator insulin-like growth factor-1, IGF-1, while the women with the adequate protein intake achieved increased muscle fiber CSA and IGF-1.

In the Health ABC study, Houston et al. (13) measured total lean mass (LM) and non-bone appendicular LM (aLM) with DXA in community-dwelling older men and women. Total, animal and vegetable protein intake were measured with a food frequency questionnaire (FFQ) at baseline and expressed in energy adjusted g/day and $\mathrm{E} \%$. The mean daily protein intake was $0.9 \mathrm{~g} / \mathrm{kg} \mathrm{BW}$, and after 3-year follow-up the mean decrease in LM and aLM was $0.68 \pm 1.94$ and $0.48 \pm 1.08 \mathrm{~kg}$, respectively. Those in the highest quintile of protein intake $(\approx 19 \mathrm{E} \%)$ lost 
Table 1. Summary table N-balance studies

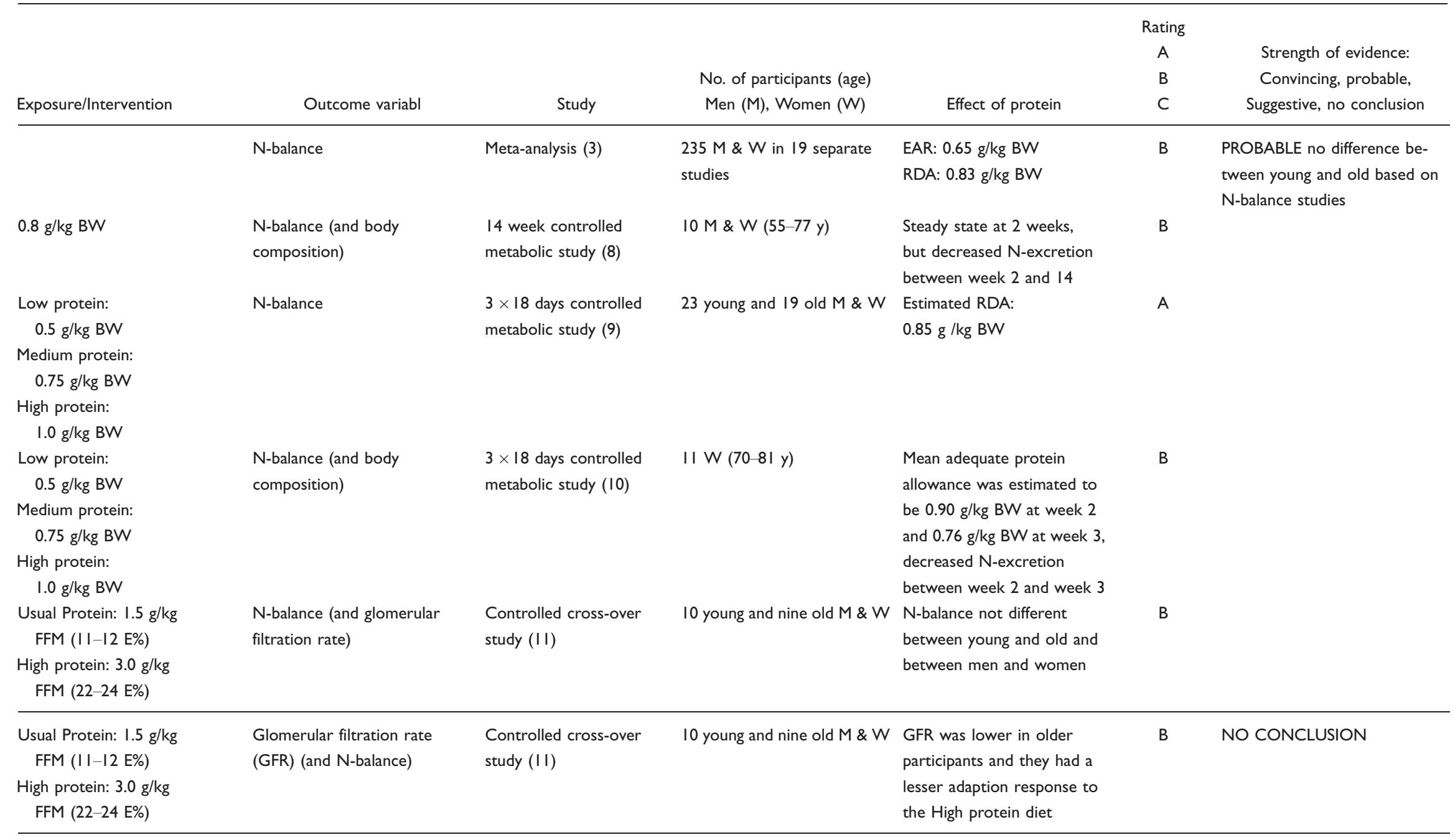

General remark for Summary tables:

POS: positive association/effect.

INVERSE: negative association/effect.

NS: statistically non-significant association/effect.

NA: non-available. 
$40 \%$ less LM and aLM compared to the lowest quintile $(\approx 11 \mathrm{E} \%)$. The change in LM and aLm was statistically significant related to total and animal protein intake, but not to vegetable protein intake. However, there was no statistically significant difference in loss of LM between quintiles among the subgroup of weight stable participants $(49.5 \%)$.

As part of a prospective randomized controlled cohort trial of supplemental calcium to prevent fractures, Meng et al. (14) analyzed the association between total protein intake and body composition after 5 years, expressed as LM and bone mineral content (BMC) in elderly women. They found that those in the highest tertile of total protein intake (T3: $>1.6 \mathrm{~g} / \mathrm{kg} \mathrm{BW}$ or $20 \mathrm{E} \%$ ) compared to the lowest tertile (T1: $0.85 \mathrm{~g} / \mathrm{kg} \mathrm{BW}$ or $18 \mathrm{E} \%$ ) had higher LM (T3: $37.4 \pm 4.8 \mathrm{~kg}$ versus $\mathrm{T} 1$ : $35.5 \pm 4.5 \mathrm{~kg}$ ) and BMC, independent of age, body size, energy intake and physical activity. The energy intake in the lowest tertile of protein intake $(\approx 5.3 \mathrm{MJ})$ indicates underreporting, and thus the actual protein intake is difficult to assess.

The evidence is assessed as suggestive regarding a positive relation between muscle mass and total protein intake in the range of 13-20 E\% (Table 2).

\section{Protein intake and bone health}

The evaluation of the association between protein and bone health is based on two randomized controlled trials, eight prospective cohort studies, and one case-control study, see Appendix 4, Table 3.

\section{Bone mineral density/bone mineral content}

One intervention study (15), quality graded as $\mathrm{C}$, and three cohort studies $(14,16,17)$, quality graded as $\mathrm{C}$, $\mathrm{B}$ and $\mathrm{B}$, respectively, were identified on the association between protein and bone mineral density (BMD) or BMC.

In a randomized controlled study, Dawson-Hughes et al. (15) exchanged carbohydrates isocalorically with meat resulting in a HP diet (HP: $24 \pm 8 \mathrm{E} \%$ ) and compared this with a low protein diet (LP: $16 \pm 3 \mathrm{E} \%$ ) among 32 elderly men and women. After 9 weeks, the HP group had increased BMC and IGF-1 compared to the LP group. The reported dietary intakes indicated underreporting (an energy intake of ca. $6 \mathrm{MJ}$ ), thus the actual protein intake is unknown.

The association between total protein intake and the relation to BMD after 1-year follow-up was assessed among Australian elderly women (16). Compared to the lowest tertile of protein intake, the two highest tertiles $(>0.84 \mathrm{~g} / \mathrm{kg} \mathrm{BW})$ together was associated with higher $\mathrm{BMD}$ at the hip. There was no baseline measurement of BMD.

As part of a prospective randomized controlled cohort trial of supplemental calcium to prevent fractures,

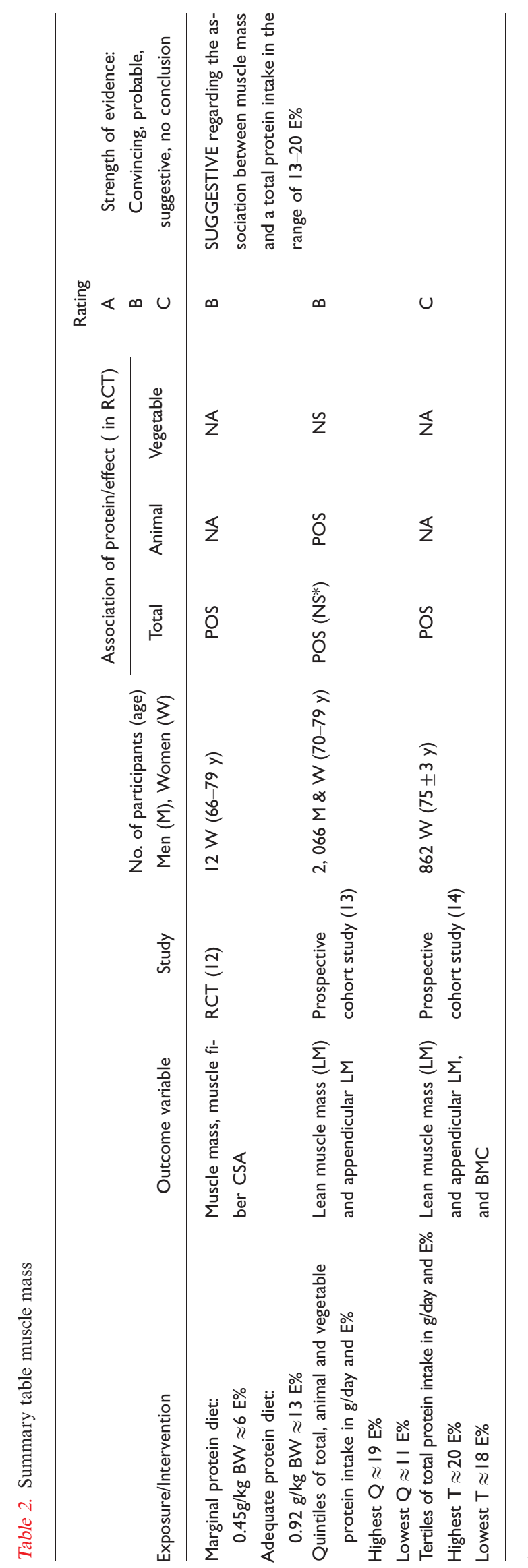

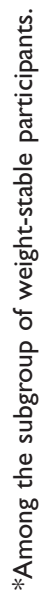


Meng et al. (14) analyzed the association between total protein intake and body composition after 5 years, expressed as LM and BMC in elderly women. They found that those in the highest tertile of total protein intake $(>1.6 \mathrm{~g} /$ $\mathrm{kg} \mathrm{BW}$ or $20 \mathrm{E} \%)$ compared to the lowest tertile $(0.85 \mathrm{~g} /$ $\mathrm{kg}$ BW or $18 \mathrm{E} \%$ ) had a $6 \%$ higher BMC. The energy intake in the lowest tertile of protein intake $(\approx 5.3 \mathrm{MJ})$ indicates underreporting, and thus the actual protein intake is difficult to assess.

The Rancho Bernardo study among men and women (17) reported an inverse association between vegetable protein intake (energy adjusted g/day) and BMD after 4 years. Among women only, there was a positive association between animal protein intake and 4-year-BMD for every $15 \mathrm{~g} /$ day increase.

The evidence is assessed as suggestive regarding a positive association between protein intake and BMD, but the protein intake level is unknown due to underreporting (Table 3).

Bone loss

One intervention study (18), quality graded as B, and four prospective cohort studies, two quality graded as B (17, $19)$, and two quality graded as $C(20,21)$, were identified on the association between protein intake and bone loss, see Appendix 4, Table 3.

In a randomized controlled trial with calcium and vitamin D supplementation versus placebo, DawsonHughes and Harris (18) compared habitual dietary protein intake with a 3-year change in BMD. The highest tertile (20 $\mathrm{E} \%$ or $1.2 \mathrm{~g} / \mathrm{kg} \mathrm{BW}$ ) was associated with less bone loss compared to lowest tertile (14 $\mathrm{E} \%$ or $1.1 \mathrm{~g} / \mathrm{kg} \mathrm{BW}$ ), but only in the intervention group. The habitual mean intake in the placebo group was $871 \mathrm{mg}$ calcium and ca. $7 \mu \mathrm{g}$ vitamin $\mathrm{D}$.

In the Framingham Osteoporosis Study, Hannan et al. (19) examined 4-year bone loss (change in BMD) among men and women, and found an inverse relation for bone loss to total and animal protein intake expressed as $\mathrm{E} \%$, but no statistically significant association to vegetable protein. Mean total protein intake was $16 \mathrm{E} \%$ and mean animal protein intake accounted for $10 \mathrm{E} \%$. Expressed in quartiles, the lowest quartile of total protein intake (7.3-13.5 E\% or $0.21-0.71 \mathrm{~g} / \mathrm{kg} \mathrm{BW})$ had the greatest bone loss, and the highest quartile (19.9-27.4 $\mathrm{E} \%$ or $1.23-2.78 \mathrm{~g} / \mathrm{kg} \mathrm{BW}$ ) showed the lowest bone loss. A similar association was seen for animal protein intake.

In the Rancho Bernardo study among men and women (17), the annual change in BMD during 4 years did not show a statistically significant association to baseline protein intake.

In an osteoporosis intervention study (the STOP IT trial), 96 women of the placebo group were followed prospectively for 3 years (20). Baseline protein intake was expressed as quartiles of protein intake in $\mathrm{E} \%$, whereas BMD was measured at baseline and after 3 years. The lowest quartile of total protein intake $(\approx 13 \mathrm{E} \%)$ was not associated with bone loss when compared to the highest quartile ( $\approx 20 \mathrm{E} \%$ ).

The Study of Osteoporotic Fractures in postmenopausal women (21) expressed the protein intake in an animal/ vegetable $(\mathrm{A} / \mathrm{V})$ ratio. $72 \%$ of the total protein intake was from animal sources. They found a positive association between the $\mathrm{A} / \mathrm{V}$ ratio and the rate of bone loss after 3.6 years.

The evidence is assessed as inconclusive regarding the relation of protein intake to bone loss (Table 3).

Bone fracture

Two prospective cohort studies $(21,22)$, quality graded as $\mathrm{C}$, and B, respectively, and a case-control study (23), quality graded as $\mathrm{B}$, were identified on the association between protein and risk of fractures, see Appendix 4, Table 3.

The Study of Osteoporotic Fractures in postmenopausal women (21) expressed the protein intake in an animal/ vegetable $(\mathrm{A} / \mathrm{V})$ ratio. $72 \%$ of the total protein intake was from animal sources. They found an increased risk of hip fractures after 7 years related to the $\mathrm{A} / \mathrm{V}$ ratio. When the model was adjusted for $\mathrm{BMD}$, the relation of $\mathrm{A} / \mathrm{V}$ ratio to fracture risk became non-significant. The protein intake assessment was flawed by a substantial underreporting, that is, $\approx 5 \mathrm{MJ}$.

In the Framingham Osteoporosis Study (22), men and women had their risk of hip fractures assessed after 11.6 person years. The authors found that the upper three quartiles of total protein intake expressed as energy adjusted g/day, compared to the lowest quartile, were associated with a $37 \%$ lower risk of hip fracture.

In a case-control study from 1997 to 2001 including men and women stratified by age groups $50-69$ or $70-89$ years (23), the intake data (obtained after an average of 4.2 months) of total, animal and vegetable protein $\mathrm{E} \%$ were expressed in quartiles. The lowest quartile of total protein intake was $5.6-13.9 \mathrm{E} \%$ and the highest quartile was $17.4-30.8 \mathrm{E} \%$. Animal protein intake was about $2 / 3$ of the total intake. Highest versus lowest quartile of total, animal and vegetable protein were all inversely related to risk of osteoporotic hip fractures, but only among the age group 50-69 years.

The evidence is assessed as inconclusive regarding the relation of protein intake to risk of fractures (Table 3).

Only one study was identified on the association between protein intake and risk of falls (24) and thus, the evidence is assessed as inconclusive. This study found no statistically significant associations between falls and total animal and vegetable protein intake after 12 months follow-up; see Appendix 4, Table 3. 


\begin{tabular}{|c|c|c|c|c|c|c|c|c|}
\hline \multirow[b]{3}{*}{ Exposure/Intervention } & \multirow{3}{*}{$\begin{array}{l}\text { Outcome } \\
\text { variable }\end{array}$} & \multirow[b]{3}{*}{ Study } & \multirow{3}{*}{$\begin{array}{l}\text { No. of participants (age) } \\
\text { Men (M), Women (W) }\end{array}$} & \multicolumn{5}{|c|}{ Rating } \\
\hline & & & & \multicolumn{3}{|c|}{ Association of protein/effect ( in RCT) } & \multirow{2}{*}{$\begin{array}{l}\text { A } \\
B \\
C\end{array}$} & \multirow{2}{*}{$\begin{array}{l}\text { Strength of evidence: } \\
\text { Convincing, probable, } \\
\text { suggestive, no conclusion }\end{array}$} \\
\hline & & & & Total & Animal & Vegetable & & \\
\hline $\begin{array}{l}\text { LP diet: } 16 \pm 3 \text { E\% protein } \\
\text { HP diet: } 24 \pm 8 \text { E\% protein }\end{array}$ & BMC & RCT (I5) & $\begin{array}{l}32 \text { M \& W } \\
16 \text { LP }(71.8 \pm 98 y) \\
16 \operatorname{HP}(64.6 \pm 10.8 y)\end{array}$ & POS & NA & NA & C & $\begin{array}{l}\text { SUGGESTIVE for total } \\
\text { protein intake and BMD }\end{array}$ \\
\hline $\begin{array}{l}\text { Total protein intake in } \mathrm{g} / \text { day and in E\% expressed in tertiles } \\
\text { TI: }<66 \mathrm{~g} / \mathrm{d} \\
\text { T3: }>87 \mathrm{~g} / \mathrm{d}\end{array}$ & BMD & $\begin{array}{l}\text { Prospective } \\
\text { cohort (16) }\end{array}$ & I,077W $(75 \pm 3 y)$ & POS & NA & NA & B & \\
\hline $\begin{array}{l}\text { Total protein intake in } g / \text { day expressed in tertiles } \\
\mathrm{TI}: 0.84 \mathrm{~g} / \mathrm{kg} \mathrm{BW} \text { or } 18 \mathrm{E} \% \\
\text { T3: }>1.6 \mathrm{~g} \mathrm{~kg} \mathrm{BW} \text { or } 20 \mathrm{E} \%\end{array}$ & BMD & $\begin{array}{l}\text { Prospective } \\
\text { cohort (14) }\end{array}$ & $862 W(75 \pm 3 y)$ & POS & NA & NA & $C$ & \\
\hline $\begin{array}{l}\text { Total, animal and vegetable protein intake } \\
\text { Energy adjusted in g/day }\end{array}$ & BMD & $\begin{array}{l}\text { Prospective } \\
\text { cohort (17) }\end{array}$ & $572 M \& W$ & NS & $\begin{array}{l}\text { POS } \\
\text { (W only) }\end{array}$ & INVERSE & B & \\
\hline $\begin{array}{l}\text { Habitual protein intake (total, animal and vegetable) } \\
\text { expressed as E\% in tertiles in combination with } 500 \mathrm{mg} \\
\mathrm{Ca} \text { and } 17.5 \mu \mathrm{g} \text { vitamin D or placebo Highest tertile } \\
\text { TI:14 E\% or } 1.1 \mathrm{~g} / \mathrm{kg} \mathrm{BW} \\
\text { T3: } 20 \mathrm{E} \% \text { or } 1.2 \mathrm{~g} / \mathrm{kg} \mathrm{BW}\end{array}$ & Bone loss & RCT (18) & $342 M \& W(\geq 65 y)$ & $\begin{array}{l}\text { INVERSE } \\
\text { (only in the } \\
\text { supplemented } \\
\text { group) }\end{array}$ & NS & NS & B & NO CONCLUSION \\
\hline $\begin{array}{l}\text { Total, animal and vegetable protein intake expressed as } \mathrm{E} \% \\
\text { and in quartiles } \\
\text { Q } \approx 7-13 \mathrm{E} \% \\
\mathrm{Q} 4 \approx 18-27 \mathrm{E} \% \\
\text { Animal protein } \approx 2 / 3 \text { of total intake }\end{array}$ & $\begin{array}{l}\text { bone loss } \\
\text { (BMD at femoral } \\
\text { neck and spine) }\end{array}$ & $\begin{array}{l}\text { Prospective } \\
\text { cohort (19) }\end{array}$ & $615 M \& W(68-91$ y) & INVERSE & INVERSE & NS & B & \\
\hline $\begin{array}{l}\text { Total, animal and vegetable protein intake } \\
\text { Energy adjusted in g/day }\end{array}$ & $\begin{array}{l}\text { annual bone loss } \\
\text { during } 4 \text { y } \\
\text { (BMD at hip, } \\
\text { femur and spine) }\end{array}$ & $\begin{array}{l}\text { Prospective } \\
\text { cohort (17) }\end{array}$ & $572 M \& W$ & NS & NS & NS & B & \\
\hline $\begin{array}{l}\text { Total protein intake in E\% expressed in Quartiles. } \\
\qquad \begin{array}{l}\text { QI } \approx 13 \mathrm{E} \% \\
\text { Q4 } \approx 20 \mathrm{E} \%\end{array}\end{array}$ & bone loss & $\begin{array}{l}\text { Prospective } \\
\text { cohort (20) }\end{array}$ & $92 \mathrm{~W}(65-77 \mathrm{y})$ & NS & NA & NA & C & \\
\hline $\begin{array}{l}\text { Energy adjusted protein intake }(\mathrm{E} \%) \text { and the ratio of animal } \\
\text { to vegetable protein ( } \mathrm{A} / \mathrm{V} \text { ratio) in tertiles. }\end{array}$ & bone loss & $\begin{array}{l}\text { Prospective } \\
\text { cohort (2I) }\end{array}$ & $742 W(>65 y)$ & NA & POS* & NA & $\mathrm{C}$ & \\
\hline Total protein intake expressed as energy adjusted g/day in & Fracture risk & Prospective & 946 M \& W (app 75 y) & INVERSE** & NA & NA & B & NO CONCLUSION \\
\hline
\end{tabular}




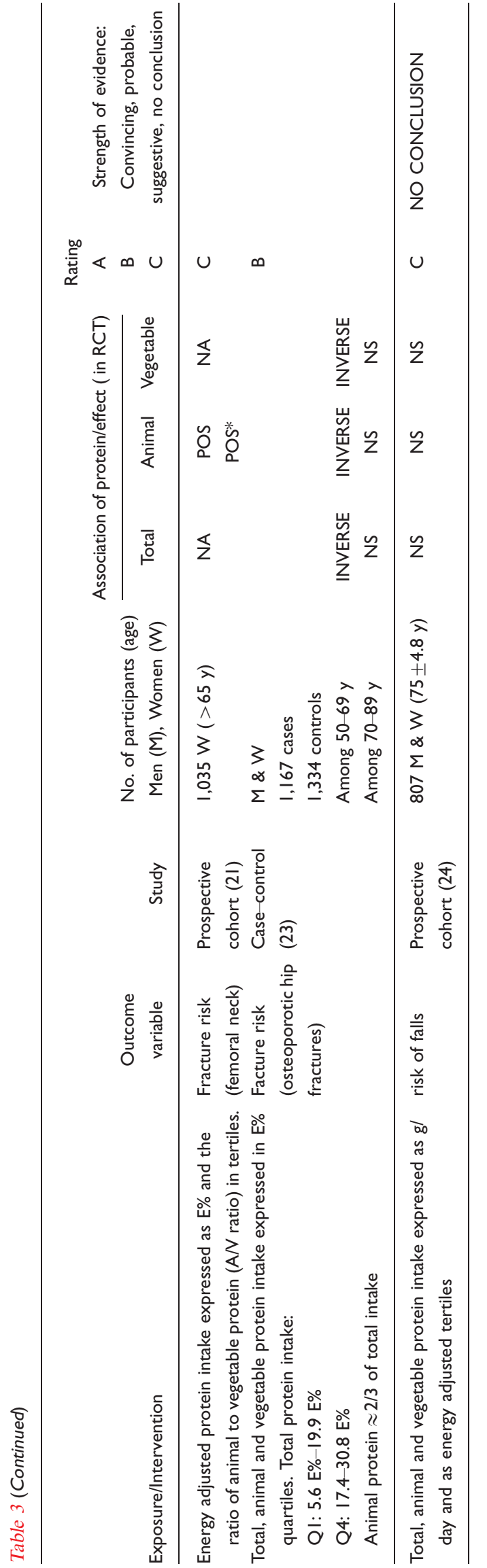

\section{Protein intake and physical training}

The evaluation of the association between protein and physical training is based on only two randomized controlled trials $(25,26)$, both quality assessed as B, see Appendix 4, Table 4.

In a strictly controlled metabolic study by Campbell et al. (25), all subjects were assured to have a regular protein intake of $0.8 \mathrm{~g}$ protein $/ \mathrm{kg}$ BW per day in euenergetic menus in order to maintain BW stability, whereas they were randomized to resistance training or a sedentary behavior for 12 weeks. The 17 old adults (mean age about 65 years) who trained were able to increase strength and their muscle mid-thigh area (measured with $\mathrm{CT}$ ), whereas fat-free mass and body water (measured with deuterium dilution) decreased. The sedentary group had a decrease in mid-thigh muscle area by an intake of $0.8 \mathrm{~g}$ protein $/ \mathrm{kg} \mathrm{BW}(\approx 10 \mathrm{E} \%)$.

The study by Haub et al. (26) showed that the effect on strength and muscle mass by resistance training for 12 weeks in 21 men aged $65 \pm 5$ years during weight stability did not differ with protein source, that is, beef-containing diet or lacto-ovo-vegetarian diet. The diets altogether provided more than $1 \mathrm{~g}$ protein $/ \mathrm{kg}$ BW per day (range $1.03-1.17 \mathrm{~g} / \mathrm{kg} \mathrm{BW}$ ). Both groups had increased muscle mass and strength.

Due to few studies, the evidence is assessed as inconclusive regarding the relation of total protein intake and sources of protein (animal versus vegetable protein) to muscle mass and body composition in combination with resistance training.

\section{Protein intake and various outcomes}

For some outcomes, only one study was identified on the association to protein intake and thus, the evidence is assessed as inconclusive; see Appendix 3, Table 5.

\section{Blood pressure}

The Rotterdam prospective cohort study (27), quality graded as B, studied the association between risk of hypertension and intake of energy adjusted tertiles of total animal and vegetable protein among persons $\geq 55$ years of age without hypertension at baseline. The lowest tertile of total protein intake was $70 \pm 15 \mathrm{~g} /$ day $(14 \mathrm{E} \%)$ and the highest was $97 \pm 19 \mathrm{~g} /$ day $(19 \mathrm{E} \%)$. They found that among persons $\geq 70$ years of age animal protein intake was related to increased risk of hypertension after 6 years follow-up, otherwise no statistically significant associations were observed.

Frailty

In the Women's Health Initiative Observational Study (WHI-OS), quality graded as B, Beasley at al studied the risk of incident frailty among 24,471 non-frail elderly women (28). The assessed protein intake with the use of FFQ was calibrated according to a study with objective 
biomarkers of energy intake (doubly labeled water) and protein intake (urinary nitrogen). These results demonstrated that the FFQ reported energy intake was considerably underestimated, that protein was modestly underestimated, and thus, that protein $\mathrm{E} \%$ was overestimated. After three years, $13.5 \%$ were classified as frail. Protein intake, expressed as both uncalibrated and calibrated intake, was inversely associated to frailty, but the association was stronger for the calibrated intake.

Mortality

The British National Diet and Nutrition Survey of people aged 65 years and over (29), quality graded as C, assessed dietary intake at baseline in 1994-95 and associated the protein intake in $\mathrm{g} /$ day to all-cause mortality 14 years after. They used a 4-day weighed dietary record, but there was no further information in the paper about the method or validation. Obviously there was under-reporting among the women (energy intake $<6 \mathrm{MJ}$ ). The study reported a decreased risk of all-cause mortality associated with higher protein intake.

\section{Discussion}

The main findings of this systematic review on protein intake and the relation to health outcomes in healthy elderly populations comparable to the Nordic populations, are that the evidence is assessed probable regarding the EAR of $0.66 \mathrm{~g}$ good-quality protein $/ \mathrm{kg}$ BW/day based on N-balance studies and the subsequent estimated RDA of $0.83 \mathrm{~g}$ good-quality protein $/ \mathrm{kg} \mathrm{BW} /$ day representing the basis for an estimation of the minimum dietary protein needs of virtually all healthy elderly persons. This corresponds to an average intake of approximately $10 \mathrm{E} \%$ from protein. The estimation of an optimal level of protein intake based on the evidence from randomized controlled trials, case-control studies and prospective cohort studies of the relations of protein intake to functional outcomes (e.g. maintenance of bone mass, muscle mass and strength), morbidity, and mortality are ranging from suggestive to inconclusive, but altogether pointing in the direction of beneficial effects from a somewhat higher intake than the minimum need.

It should be noted that the grading of the evidence was only based on studies from 2000 up to and including 2011, and for some outcomes inclusion of earlier studies might have resulted in different grading. The most recent recommendations of protein intake from USA (2) and EFSA (6) are based on N-balance studies, while the relation between health outcomes and protein intake was considered insufficient to establish reference values (6) or recommendations (2). Studies with total, animal or vegetable protein were included in this review while studies at amino acid level were not included. The usual diet in the Nordic countries is considered unlikely to be limited in their content of essential amino acids, and thus, we did not regard it relevant to make an update of the comprehensive work by WHO/FAO/UNU expert group from 2007 about amino acid requirements (5). We included mainly long-term studies with only healthy old adults under free-living conditions. Postprandial (acute/single meal studies) and short-term studies, and also studies with protein isolates may not reflect the effect from ad libitum long-term dietary habits and/or mechanisms like adaptation. Studies including both healthy persons and persons with disease risk factors show different outcomes on nutrition exposures, e.g. greater reductions in LDL-cholesterol values among hypercholesterolemic individuals compared to individuals with normocholesterolemia after intervention with casein or soy protein $(30,31)$, or greater reductions in blood pressure among those with hypertension compared to normotensives after partial substitution of carbohydrate with protein (32).

\section{$\mathrm{N}$-balance studies}

$\mathrm{N}$-balance remains the method of choice for determining protein requirement in adults. Nevertheless, there are limitations in this method that need to be addressed, such as being related to the accuracy of the measurements, the short duration of the studies and the difficulty in interpretation of the results. Rand et al.'s meta-analysis (3) included $27 \mathrm{~N}$-balance studies with six studies performed in persons aged 63 and older. From those, Rand et al. selected only studies that provided individual data for persons studied at three or more levels of protein intake. Thus, Rand's estimation was based on $19 \mathrm{~N}$ balance studies with 221 'young' individuals and only 14 'old' individuals from a study by Uauy et al. (4). Rand et al. found no statistically significant differences between 'young' and 'old', sex or source of dietary protein, but the data did not provide sufficient power to detect possible differences. The median nitrogen requirement was $130.5 \mathrm{mg}$ per $\mathrm{kg}$ BW per day in the old versus 103.9 $\mathrm{mg}$ per $\mathrm{kg} \mathrm{BW}$ per day in the younger group corresponding to a difference of $0.17 \mathrm{~g}$ protein per $\mathrm{kg} \mathrm{BW}$ per day or a $26 \%$ higher requirement. The conclusion that Rand et al. draw from their analysis was that the healthy elderly may have a somewhat higher requirement, but that there was not enough evidence to give age-specific recommendations (3).

The objective of the high quality graded N-balance study by Campbell et al. (9) was to study the effect of age on the EAR. They found no difference in the EAR between the young and old participants, and the calculated adequate protein allowance of $0.85 \mathrm{~g}$ good-quality protein per kg BW per day for all participants combined was not statistically different from the RDA estimated in Rand's meta-analysis (3).

An earlier study by Campbell et al. (8) also found $0.8 \mathrm{~g}$ protein $/ \mathrm{kg}$ BW to be sufficient to obtain $\mathrm{N}$-balance 
among 10 elderly people. A short-term study (11) with only 10 days on each diet was also included in the current systematic review because a HP (22-24 E\%) intake was tested against a usual protein (11-12 $\mathrm{E} \%$ ) intake in young as well as elderly healthy participants. The net daily N-balance increased equally in the young and older participants on the HP diet.

From these studies, we assess the evidence as probable regarding the estimated EAR of 0.65 g good-quality protein $/ \mathrm{kg}$ BW/day and the resulting RDA of $0.83 \mathrm{~g}$ good-quality protein $/ \mathrm{kg} \mathrm{BW/day} \mathrm{as} \mathrm{adequate} \mathrm{to} \mathrm{meet} \mathrm{the}$ minimum dietary protein needs of virtually all healthy elderly persons.

WHO/FAO/UNU (5) based their protein requirement for elderly people on Rand et al.'s meta-analysis (3) and also on a reassessment of the N-balance studies among the elderly who were not included in the meta-analysis and, supported by additional studies with measurements of metabolic demand, WHO/FAO/UNU concluded, that 'these data lend confidence to the overall conclusion drawn from the nitrogen balance data that the physiological protein requirement does not increase with age'. Based on Rand et al. (3), Campbell et al. (8), and studies before 2000 including some short-term studies, EFSA (6) concluded that the available data are insufficient to specifically determine the protein requirement in older adults and that at least the same level of protein intake as for young adults is required for older adults. As sedentary older adults have a lower energy requirement the protein to energy ratio of this subgroup is higher than for younger adults'.

\section{Protein intake - muscle mass}

Long-term health and functional outcomes related to various protein intakes are likely of greater potential importance than $\mathrm{N}$-balance studies that only give shortterm indications on what intake is needed to prevent loss of protein mass, that is, mainly muscle mass, and bone mass. It has to be emphasized that the processes of dietary-based losses of muscle mass and strength, that is, sarcopenia, and bone, that is, osteoporosis, are extremely slow. This means that it may take many years before these losses are: (1) possible to identify with current measurement techniques (e.g. DXA); and (2) lead to compromised function, morbidity or mortality. Moreover, there is no strong consensus on what are validated or accepted outcome variables, as well as which are the most reliable biological marker of protein status.

Prevention of sarcopenia, that is, the age-related loss of muscle mass, strength and function is highly relevant. Advanced sarcopenia is a part of physical frailty and thus, associated with increased likelihood of falls and impairment in the ability to perform activities of daily living (33). The protein intake in the prevention of sarcopenia is one of many possible intervention strategies in question.

The studies included in this systematic review also point at a caveat whether the allowance represents a sufficient intake level in relation to loss of muscle mass. Campbell et al. (8) distinguish between adaption and accommodation. Adaptation refers to metabolic changes that occur in response to changes in protein intake and result in the establishment of a new steady state without a compromise or loss in physiological function, whereas accommodation refers to metabolic changes due to the decreased protein intake to establish a new steady state but at the cost of compromised physiological functions. During the small 14-week study, Campbell et al. found that urinary nitrogen excretion decreased after week 2 , and the change was associated with a loss of skeletal muscle (mid-thigh muscle area) which points at a longerterm accommodation in skeletal muscle. Additionally, Morse et al. (10) found a decrease in nitrogen excretion between week 2 and week 3 in an 18-day study, but they found no changes in fat-free mass.

Based on a small randomized controlled trial (12) and two prospective cohort studies $(13,14)$ with $3-5$ years follow-up, we assessed the evidence of a relation between prevention of loss of muscle mass and a total protein intake in the range of 13-20 E\% to be suggestive. We excluded one study (34) with 'borderline' elderly (mean age $62 \pm 7$ years) according to our eligibility criteria, but the inclusion of this study would not have changed our assessment of evidence. In a strictly controlled metabolic study with focus on N-balance (8) and on resistance training (25), Campbell et al. found that a protein intake of $0.8 \mathrm{~g} / \mathrm{kg} \mathrm{BW}(\approx 10 \mathrm{E} \%)$ during 14 weeks resulted in a loss of mid-thigh muscle area in the sedentary control group during BW stability. In the Health ABC Study (13), that is the first longitudinal study to examine the role of dietary protein on changes in body composition by using state-of-art-body-composition measurements, the mean protein intake was $0.9 \mathrm{~g} / \mathrm{kg} \mathrm{BW}$ and the mean 3 -year loss of lean body mass was $0.68 \pm 1.9 \mathrm{~kg}$. Subjects in the highest quintile of protein intake $(\approx 19 \mathrm{E} \%)$ lost less LM compared to those in the lowest quintile $(\approx 11$ $\mathrm{E} \%$ ). But of notice is that there was no statistically significant association between total protein intake and a 3-year loss of muscle mass adjusted for physical activity in the $49.5 \%$ of participants that were weight stable, which points to the necessity of a sufficient energy intake among the elderly to keep up the protein stores.

The EFSA Panel (6) considered that in healthy adults the available data on the effects of dietary intake on muscle mass and function did not provide evidence to be considered as a criterion for setting a population reference intake (PRI) and further they stated that 'There are no data showing that an additional intake of protein would increase muscle mass in different age groups who 
are in nitrogen balance, including subjects undertaking endurance or resistance exercise'.

\section{Protein intake - bone health}

During aging there is an average loss of both muscle and bone mass in the population, however, with very wide variations between individuals.

The role of dietary protein on bone health has been controversial. On the one hand, urinary calcium loss is increased by HP intakes, while on the other hand protein increases calcium absorption or bioavailability, which questions the net effect of HP diets on calcium economy and the effect on bone health (35). Any negative effect of protein may also be opposed by an increase in the protein sensitive anabolic mediator insulin-like growth factor 1, IGF-1.

We assess the evidence as suggestive for an association between protein intake and BMD. The evidence regarding the relation of protein to an overall effect on bone health based on studies with bone loss, fracture risk and falls as outcomes are according to our view point inconclusive. Thus, the conservative interpretation is in line with EFSA (6) that found the available evidence regarding protein and bone health to be insufficient.

The positive association between protein intake and BMD/BMC was based on one intervention study (15), and three prospective cohort studies $(14,16,17)$, but even though the effect was observed with protein intakes above approximately $0.85 \mathrm{~g} / \mathrm{kg} \mathrm{BW}$ or $16-18 \mathrm{E} \%$, the actual protein intake level was unknown due to underreporting. In the 5-year cohort study by Meng et al. (14), where lean body mass as well as BMC was measured they found that the association between protein intake and $\mathrm{BMC}$ disappeared after further adjustment for LM. Thus, the authors concluded that the protein effect on bone mass may be partly mediated by its effect on muscle. In the randomized controlled study with calcium and vitamin D supplementation by Dawson-Hughes and Harris (18), the highest tertile of protein intake $(20 \mathrm{E} \%$ or $1.2 \mathrm{~g} / \mathrm{kg}$ $\mathrm{BW}$ ) was associated with less bone loss compared to the lowest tertile (14 E\% or $1.1 \mathrm{~g} / \mathrm{kg} \mathrm{BW})$, but only in the intervention group. Interestingly, the habitual mean intake in the placebo group was $871 \mathrm{mg}$ calcium and approximately $7-\mu \mathrm{g}$ vitamin $\mathrm{D}$, which closely corresponds to the NNR from 2004 (1). Thus, the possible effect of protein intake on bone health may depend on an intake level of calcium and vitamin D above the current recommendations.

A prospective cohort study (22) and a case-control study (23) found total protein intake associated with a decreased risk of fractures, but in the case-control study it was only statistically significant among 50-69-year-old participants, while the association was non-significant among the 70-79-year-old participants (23). In the Study of Osteoporotic Fractures in postmenopausal women
(21), a high $\mathrm{A} / \mathrm{V}$ ratio was associated with an increased risk of fractures.

Overall, the animal protein intake showed both positive $(17,19,23)$ and negative (21) effects on bone health, while no detrimental effect of total protein intake was observed. No upper limit could be detected for total protein intake in relation to bone health. The study by Hannan et al. (19) even found that elderly with total protein intake up to three times RDA (1.2-2.8 g/kg BW or $18-27 \mathrm{E} \%$ ) had the least bone loss after controlling for known confounders, including weight changes.

\section{Protein intake - physical exercise}

Only few studies address the issue of regular protein intake for optimal effect of physical exercise in healthy old adults. We included two American medium term $\operatorname{RCTs}(25,26)$ that evaluate if the amount or the quality of the protein intake have different effects on muscle mass gain or strength by $\sim 3$ months of resistance training. Due to the few studies, we assess the evidence to be inconclusive.

In addition, there are studies that use supplementation of protein hydrolysates in order to increase the protein intake during periods of resistance training. Such studies fall outside the scope of this review of effects by regular food, but they still provide understanding of potential effects of combined training and increased protein intake, and are thus mentioned briefly. A recent meta-analysis by Cermak et al. from 2012 (36) combined the results from six studies performed in 'older' subjects, and it was concluded that protein supplementation - provided either by supplement or via the habitual diet corresponding to $42 \pm 30 \mathrm{~g}$ - increased the effects on muscle mass by an additional $38 \%$ as well as a $33 \%$ greater increase in muscle strength (1-RM leg press strength). It should be observed that the authors set the distinction between young and old at 50 years of age. In all but one study participant, average age was below 65 years. However, Verdijk et al. (37) evaluated the effect of $20 \mathrm{~g}$ extra protein given three times/week in conjunction with exercise during 12 weeks in 26 healthy men (average age $72 \pm 2$ years). No further effect on muscle mass or strength of the protein supplementation was observed. Neither was an effect on total protein intake by the supplementation observed, that is, intake being constant at $1.1 \mathrm{~g} / \mathrm{kg} /$ day in both groups. Interestingly, the separate studies in the meta-analysis by Cermak et al. could not themselves establish evidence for positive effects by supplementation, mainly due to underpowered study designs.

There are two short-term studies that also should be mentioned regarding timing. In the study by Andrews et al. (38), fifty 60-69 year-old subjects were provided a post-exercise drink with $0.4 \mathrm{~g}$ protein/kg/day during 12 weeks leading to a range of daily protein intake from 0.72 to $1.35 \mathrm{~g} / \mathrm{kg}$. Variability in mean daily protein 
intake was not associated with a change in LM. In contrast to these results, Esmarck et al. (39) reported that a protein supplementation of $10 \mathrm{~g}$ given directly in connection with the training session had positive effects on muscle hypertrophy, mean fiber area and strength, whereas a corresponding intake $2 \mathrm{~h}$ after the training session could not provide these effects.

\section{Protein intake - various outcomes}

Some outcomes, that is, hypertension, frailty, and mortality, were only addressed in one article, and thus, the evidence was assessed as inconclusive.

\section{Potential risks}

Potential risks, e.g. kidney damage or hypertension, of HP intakes need to be addressed. The N-balance study by Walrand et al. (11) found that baseline GFR was lower in the old participants compared to the young participants. The study reported that a HP intake corresponding to $24 \mathrm{E} \%$ did not increase GFR in the old participants. This is probably due to the reduced kidney function in elderly, since patients with mild-to-moderate chronic kidney disease also do not show the usual protein-induced increase in GFR (40). The increase in GFR is a normal physiological adaption to increased protein intake (41) but it is also an important component of the hyperfiltration theory of Brenner (42) due to its presumed effect of increasing glomerular pressure. It is also an important component of the hyperfiltration theory that protein overloading of remnant nephron mass should be avoided.

In a prospective cohort study (27), it was reported that animal protein intake increased the risk of hypertension only among persons $\geq 70$ years of age after 6 years follow-up.

\section{Methodological problems}

Except from the strictly controlled metabolic studies it has generally been difficult to assess the actual protein intake in the observational studies due to misreporting (underreporting). The FFQ is a widespread dietary assessment method in observational studies. Based on a thorough calibration study, Beasley et al. (28) concluded that FFQ better assess nutrient consumption as a fraction of total energy intake than absolute nutrient consumption. Thus, it may be more appropriate to conclude from protein $\mathrm{E} \%$ than protein intake expressed in g per day or per $\mathrm{kg} \mathrm{BW}$.

Still, taken together studies on protein intake and longterm outcomes related to muscle mass $(8,12-14,25)$, bone mass $(14-16,18)$, and frailty (28) altogether indicate that there are suggestive evidence for positive effects of a higher intake than the $0.83 \mathrm{~g} / \mathrm{kg} \mathrm{BW} /$ day recommendations based on $\mathrm{N}$-balance studies only.

\section{Conclusion}

The evidence is assessed as probable for an EAR of $0.66 \mathrm{~g}$ protein/kg BW/day based on N-balance studies and the subsequent RDA of $0.83 \mathrm{~g}$ good-quality protein $/ \mathrm{kg} \mathrm{BW} /$ day (i.e. approximately $10 \mathrm{E} \%$ ) representing the minimum dietary protein needs of virtually all healthy elderly persons.

There are still only few studies in this particular population and no new data justify a modification from the current estimated requirement.

The progressive loss of muscle mass and function (sarcopenia) as well as osteoporosis are true problems of the old population. It is likely to assume that these processes are too slow for short-term $\mathrm{N}$-balance studies as well as short-term intervention studies to discover potentially beneficial effects from a slightly increased protein intake.

The estimation of an optimal level of protein intake based on the evidence from randomized controlled trials, case-control studies and prospective cohort studies of the relations of protein intake to functional outcomes (e.g. maintenance of bone mass, muscle mass and strength), morbidity, and mortality are ranging from suggestive to inconclusive. In particular, some long-term prospective studies indicate that an intake of up to at least $1.2-1.5 \mathrm{~g}$ protein/kg BW/day (i.e. approximately $15-20 \mathrm{E} \%$ ) is safe and may have beneficial effects. Still, adequate enough data do not exist to estimate this optimal intake of protein based on the main physiological end points in the elderly.

Overall, many of the included prospective cohort studies were difficult to fully evaluate since results mainly were obtained by FFQs that were flawed by underreported intakes, despite some studies were 'calibrated' to correct for under- or over-reporting.

The overall impression from the included studies in the systematic review is that the optimal protein intake may be higher than the estimated RDA assessed from N-balance studies, whereas an exact level cannot be determined.

Regarding harmful effects of a HP intake, the evidence is considered as inconclusive. It cannot be ruled out that a HP intake corresponding to approximately $24 \mathrm{E} \%$ or $2 \mathrm{~g}$ protein/kg BW and day may affect kidney function negatively among old adults.

\section{Acknowledgements}

Special thanks to the librarians Hege Sletsjøe and Jannes Engqvist, and to Ulla-Kaisa Koivisto Hursti and Wulf Becker for their help and guidance.

\section{Conflict of interest and funding}

The authors have not received any funding or benefits from industry or elsewhere to conduct this study.

\section{References}

1. Nordic Nutrition Recommendations 2004. Integrating nutrition and physical activity. 4th ed. Copenhagen: Nordic Council of Ministeres; 2004. Nord 2004:13.

2. Institute of Medicine (2002). Dietary reference intakes for energy, carbohydrates, fiber, fat, protein and Amino Acids (Macronutrients). Washington, DC: Food Nutrition Board. 
3. Rand WR, Pellett PL, Young VR. Meta-analysis of nitrogen balance studies for estimating protein requirements in healthy adults. Am J Clin Nutr 2003; 77: 109-27.

4. Uauy R, Scrimshaw NS, Young VR. Human protein requirements: nitrogen balance response to graded levels of egg protein in elderly men and women. Am J Clin Nutr 1978; 31: 779-85.

5. WHO/FAO/UNU (2007). Protein and amino acids requirements in human nutrition: report of a Joint WHO/FAO/UNU Expert Consultation. WHO Technical Series; no.935. Geneva, Switzerland: World Health Organization.

6. EFSA Panel on Dietetic Products, Nutrition and Allergies (NDA). Scientific opinion on dietary reference values for protein. EFSA J 2012; 10: 2557.

7. NNR5 Working group. A guide for conducting systematic literature reviews for the 5th edition of the Nordic Nutrition Recommendations. Revised ed. Copenhagen: Nordic Council of Ministers; 2011. Available at http://www.slv.se/upload/NNR5/ A $\% 20$ guide $\% 20$ for $\% 20$ conducting $\% 20$ SLR $\% 20$ for $\% 20$ NNR $5 \%$ 20FINAL.pdf.

8. Campbell WW, Trappe TA, Wolfe RR, Evans WJ. The recommended dietary allowance for protein may not be adequate for older people to maintain skeletal muscle. J Gerontol 2001; 56A: M373-80.

9. Campbell WW, Johnson CA, McCabe GP, Carnell NS. Dietary protein requirements of younger and older adults. Am J Clin Nutr 2008; 88: 1322-9.

10. Morse MH, Haub MD, Evans WJ, Campbell WW. Protein requirement of elderly women: nitrogen balance responses to three levels of protein intake. J Gerontol 2001; 56A: M724-30.

11. Walrand S, Short KR, Bigelow ML, Sweatt AJ, Hutson SM, Nair KS. Functional impact of high protein intake on healthy elderly people. Am J Physiol Endocrinol Metab 2008; 295: E921-8.

12. Castaneda C, Gordon PL, Fielding RA, Evans WJ, Crim MC. Marginal protein intake results in reduced plasma IGF-I levels and skeletal muscle fiber atrophy in elderly women. J Nutr Health Aging 2000; 4: 85-90.

13. Houston DK, Nicklas BJ, Ding J, Harris TB, Tylavsky FA, Newman AB, et al. Dietary protein intake is associated with lean mass change in older, community-dwelling adults: the health, aging, and body composition (Health $\mathrm{ABC}$ ) study. Am J Clin Nutr 2008; 87: 150-5.

14. Meng X, Zhu K, Devine A, Kerr DA, Binns CW, Prince RL. A 5-year cohort study of the effects of high protein intake on lean mass and BMC in elderly postmenopausal women. J Bone Miner Res 2009; 24: 1827-34.

15. Dawson-Hughes B, Harris SS, Rasmussen H, Song L, Dallal GE. Effect of dietary protein supplements on calcium excretion in healthy older men and women. J Clin Endocrinol Metab 2004; 89: 1169-73.

16. Devine A, Dick IM, Islam AFM, Dhaliwal SS, Prince RL. Protein consumption is an important predictor of lower limb bone mass in elderly women. Am J Clin Nutr 2005; 81: 1423-8.

17. Promislow JHE, Goodman-Gruen D, Slymen DJ, BarrettConnor E. Protein consumption and bone mineral density in the elderly. Am J Epidemiol 2002; 155: 636-44.

18. Dawson-Hughes B, Harris SS. Calcium intake influences the association of protein intake with rates of bone loss in elderly men and women. Am J Clin Nutr 2002; 75: 773-9.

19. Hannan MT, Tucker KL, Dawson-Hughes B, Cupples LA, Felson DT, Kiel DP. Effect of dietary protein on bone loss in elderly men and women: the Framingham Osteoporosis Study. J Bone Miner Res 2000; 15: 2504-12.

20. Rapuri PB, Gallagher JC, Haynatzka V. Protein intake: effects on bone mineral density and the rate of bone loss in elderly women. Am J Clin Nutr 2003; 77: 1517-25.
21. Sellmeyer DE, Stone KL, Sebastian A, Cummings SR. A high ratio of dietary animal to vegetable protein increases the rate of bone loss and the risk of fracture in postmenopausal women. Study of Osteoporotic Fractures Research Group. Am J Clin Nutr 2001; 73: 118-22.

22. Misra D, Berry SD, Broe KE, McLean RR, Cupples LA, Tucker $\mathrm{KL}$, et al. Does dietary protein reduce hip fracture risk in elders? The Framingham Osteoporosis Study. Osteoporos Int 2011; 22: 345-9.

23. Wengreen HJ, Munger RG, West NA, Cutler DR, Corcoran $\mathrm{CD}$, Zhang $\mathrm{J}$, et al. Dietary protein intake and risk of osteoporotic hip fracture in elderly residents of Utah. Bone Miner Res 2004; 19: 537-45.

24. Zoltick ES, Sahni S, McLean RR, Quach L, Casey VA, Hannan MT. Dietary protein intake and subsequent falls in older men and women: the Framingham Study. J Nutr Health Aging 2011; 15: $147-52$

25. Campbell WW, Trappe TA, Jozsi AC, Kruskall LJ, Wolfe RR, Evans WJ. Dietary protein adequacy and lower body versus whole body resistive training in older humans. J Physiol 2002; 542: 631-42.

26. Haub MD, Wells AM, Tarnopolsky MA, Campbell WW. Effect of protein source on resistive-training-induced changes in body composition and muscle size in older men. Am J Clin Nutr 2002; 76: 511-7.

27. Altorf-van der Kuil W, Engberink MF, van Rooij FJ, Hofman A, van't Veer P, Witteman JC, et al. Dietary protein and risk of hypertension in a Dutch older population: the Rotterdam study. J Hypertens 2010; 28: 2394-400.

28. Beasley JM, LaCroix AZ, Neuhouser ML, Huang Y, Tinker L, Woods $\mathrm{N}$, et al. Protein intake and incident frailty in the Women's Health Initiative observational study. J Am Geriatr Soc 2010; 58: 1063-71.

29. Bates CJ, Mansoor MA, Pentieva KD, Hamer M, Mishra GD. Biochemical risk indices, including plasma homocysteine, that prospectively predict mortality in older British people: the National Diet and Nutrition Survey of People Aged 65 Years and Over. Br J Nutr 2010; 104: 893-9.

30. Anderson JW, Bush HM. Soy protein effects on serum lipoproteins: a quality assessment and meta-analysis of randomized, controlled studies. J Am Coll Nutr 2011; 30: 79-91.

31. Crouse JR 3rd, Morgan T, Terry JG, Ellis J, Vitolins M, Burke GL. A randomized trial comparing the effect of casein with that of soy protein containing varying amounts of isoflavones on plasma concentrations of lipids and lipoproteins. Arch Intern Med 1999; 159: 2070-6.

32. Appel LJ, Sacks FM, Carey VJ, Obarzanek E, Swain JF, Miller ER 3rd, et al. Effects of protein, monounsaturated fat, and carbohydrate intake on blood pressure and serum lipids: results of the OmniHeart randomized trial. JAMA 2005; 294: 2455-64.

33. Paddon-Jones D, Short KR, Campbell WW, Volpi E, Wolfe RR. Role of dietary protein in the sarcopenia of aging. Am J Clin Nutr 2008; 87: 1562S-6S.

34. Scott D, Blizzard L, Fell J, Giles G, Jones G. Associations between dietary nutrient intake and muscle mass and strength in community-dwelling older adults: the Tasmanian Older Adult Cohort Study. J Am Geriatr Soc 2010; 58: 2129-34.

35. Thorpe P, Evans EM. Dietary protein and bone health: harmonizing conflicting theories. Nutr Rev 2011; 69: 215-30.

36. Cermak NM, Res PT, de Groot LCPGM, Saris WHM, van Loon LJC. Protein supplementation augments the adaptive response of skeletal muscle to resistance training: a metaanalysis. Am J Clin Nutr 2012; 96: 1454-64. 
37. Verdijk LB, Jonkers RA, Gleeson BG, Beelen M, Meijer K, Savelberg HH, et al. Protein supplementation before and after exercise does not further augment skeletal muscle hypertrophy after resistance training in elderly men. Am J Clin Nutr 2009; 89: 608-16.

38. Andrews RD, MacLean DA, Riechman SE. Protein intake for skeletal muscle hypertrophy with resistance training in seniors. Int J Sport Nutr Exerc Metab 2006; 16: 362-72.

39. Esmarck B, Andersen JL, Olsen S, Richter EA, Mizuno M, Kjær M. Timing of postexercise protein intake is important for muscle hypertrophy with resistance training in elderly humans. J Physiol 2001; 535: 301-11.

40. Bosch JP, Lew S, Glabman S, Lauer A. Renal hemodynamic changes in humans. Response to protein loading in normal and diseased kidneys. Am J Med 1986; 81: 809-15.
41. Bankir L, Bouby N, Trinh-Trang-Tan MM, Ahloulay M, Promeneur D. Direct and indirect cost of urea excretion. Kidney Int 1996; 49: 1598-607.

42. Taal MW, Brenner BM. Renal risk scores: progress and prospects. Kidney Int 2008; 73: 1216-9.

*Agnes N. Pedersen

DTU Food, National Food Institute

Mørkhøj Bygade 19, DK-2860 Søborg

Denmark

Email: agnp@food.dtu.dk 


\section{Appendix 1. Research questions}

The effects or associations marked with * should be reviewed in cooperation with or in the relevant expert groups (e.g. infants and children, elderly, pregnant and lactating women).

1. What is the dietary requirement of protein and protein of different dietary sources for adequate growth, development and maintenance of body functions, mainly based on N-balance studies?

2. What is the association and what are the effects of different intake, timing and frequency of protein and protein of different dietary sources, while considering intake of other energy giving nutrients at the same time, on:

well-established markers or indicators of functional or clinical outcomes such as serum lipids, glucose and insulin, blood pressure, body composition and bone mineral density?

\section{functional or clinical outcomes including}

- pregnancy* or birth outcomes*, growth, development and sarcopenia*

- cardiovascular diseases, weight outcomes, cancer, type 2-diabetes, fractures, renal outcomes, physical training, muscular strength and mortality

\section{Appendix 2. Search terms}

Database: Ovid MEDLINE(R) In-Process \& Other Non-Indexed Citations and Ovid

MEDLINE(R) $<1950$ to Present $>$

Search Strategy:

1 exp Dietary Proteins/ (71799)

2 Proteins/me [Metabolism] (61274)

3 Nitrogen/me [Metabolism] (19039)

4 amino acids/ or exp amino acids, essential/ (266907)

5 exp Diet, Protein-Restricted/ or exp Diet, Vegetarian/ (3849)

6 exp Fish Proteins/ (7102)

7 exp Plant Proteins/ (112865)

8 ((egg* or yolk* or milk or animal* or diet*) adj3 protein*).tw. (30205)

9 (amino adj2 acid* adj4 (essential* or nonessential* or non essential* or dispensable* or nondispensable* or non dispensable*)).tw. (6328)

10 (diet* adj3 (low protein* or protein restricted or protein free or high protein)).tw. (5813)

11 ((Soy or soy bean* or soybean* or plant or vegetable* or fish) adj3 protein*).tw. (10738)

12 ((vegan* or vegetarian*) and protein*).tw. (444)

13 ((diet* or balance*) adj3 nitrogen*).tw. (4906)

14 or/1-13 (528777)

15 (intake* or timing* or frequen* or requirement* or utilization*).tw. (1384587)

16 nutritional requirements/ (15722)

1715 or $16(1392935)$

1814 and 17 (48263)

19 exp Lipids/bl [Blood] (164517)

20 exp Lipoproteins/ (107523)

21 exp Hyperlipidemias/ (50696)

22 cholesterol, hdl/ or cholesterol, ldl/ (27190)

23 exp Triglycerides/ (55871)

24 ((serum or blood) adj2 lipid*).tw. (21078)

25 lipoprotein*.tw. (95533)

26 hyperlipidemia*.tw. (12571)

27 (cholesterol adj2 (hdl or ldl)).tw. (35090)

28 triglyceride*.tw. (63777)

29 or/19-27 (281777)

30 exp Glucose/ (215099)

31 exp Hyperglycemia/ (20648)

32 (glucose or dextrose).tw. (280143)

33 (d glucose or 1 glucose).tw. (16987) 
34 (fasting adj3 glucose).tw. (18392)

35 (hyperglycemia or hyperglucemia or hyperglycemic or (hyper adj glycemi*)).tw. (25219)

36 (blood adj2 (sugar or glucose)).tw. (43161)

37 (glucose adj2 intoleranc*).tw. (5750)

38 or/30-37 (370848)

39 Insulin/ (142600)

40 exp Insulin Resistance/ (38231)

41 exp Hyperinsulinism/ (43180)

42 (humulin or iletin or insulin or novolin or velosulin).tw. (226819)

43 (hyperinsulin* or insulinem*).tw. (18338)

44 (insulin adj2 (sensitiv* or resistanc* or hypersensitiv*)).tw. (46353)

45 or/39-44 (270838)

46 exp Blood Pressure/ (226330)

47 exp hypertension/ (188397)

48 exp hypotension/ (21099)

49 ((blood or diastolic* or pulse or systolic*) adj2 pressur*).tw. (211754)

50 (hypertension* or hypotension*).tw. (263275)

51 or/46-49 (453970)

52 exp Body Composition/ (28527)

53 exp body mass index/ (56123)

54 exp Abdominal Fat/ (2418)

55 Waist-hip ratio/ (2052)

56 exp Adipose Tissue/ (59986)

57 (body adj2 composition*).tw. (16839)

58 (body adj2 fat* adj3 (distribution* or pattern*)).tw. (2312)

59 (body adj2 mass adj3 index).tw. (68249)

60 bmi.tw. (46648)

61 ((fat free or lean) adj3 body mass).tw. (5098)

62 (waist adj2 hip).tw. (6197)

63 adiposity.tw. (9077)

64 ((visceral or abdominal or body or pad) adj2 fat*).tw. (28631)

65 or/52-64 (192342)

66 exp "Bone and Bones"/ (429468)

67 Bone Density/ (33081)

68 exp Fractures, Bone/ (124402)

69 exp Osteoporosis/ (38044)

70 (bone or bones).tw. (430056)

71 (osteoporos* or bone loss*).tw. (47186)

72 or/66-71 (802479)

73 exp Pregnancy Outcome/ (32312)

74 exp Parturition/ (5980)

75 Abortion, Spontaneous/ (12901)

76 exp Infant, Newborn/ (447494)

77 "growth and development"/ or exp aging/ or exp growth/ (673749)

78 exp Muscular Atrophy/ (7784)

79 (birth* or childbirth* or stillbirth* or (pregnancy adj2 outcome*)).tw. (212641)

80 parturition*.tw. (10663)

81 (abortion* or miscarriage*).tw. (47509)

82 ((Infant* adj2 newborn) or neonate*).tw. (74510)

83 (Body adj2 (size or height* or weight*)).tw. (142288)

84 (cell* adj2 (growth or enlargement* or proliferation*)).tw. (182400)

85 (organ adj2 (size* or weight* or volume*)).tw. (4629)

86 (development* adj2 (human* or child* or infant* or adolescent*)).tw. (26608)

87 (aging or ageing or longevity).tw. (117701)

88 ((muscular adj2 atrop*) or sarcopenia).tw. (5675) 
89 or/73-88 (1537884)

90 exp Body Weight/ (291817)

91 ((birth or body or fetal or gain or los* or reduc* or decreas* or chang*) adj2 weight*).tw. (232690)

92 (obesit* or obese or leanness or thinness or underweight or under weight or overweight or over weight).tw. (134236)

93 (emaciation* or cachexia).tw. (5111)

94 or/90-93 (473911)

95 Cardiovascular Diseases/ (77121)

96 exp heart diseases/ (772950)

97 exp vascular diseases/ (1159229)

98 (cardio* or cardia* or heart* or vascular* or ischem* or ischeam* or coronary* or myocardial* or angina* or cvd or chd or arrythmi* or atrial* or endocardi* or fibrillate*).tw. (1595528)

99 (vascular* or thromboembolism* or thrombosis*).tw. (451761)

100 or/95-99 (2391038)

101 exp neoplasms/ (2199022)

102 (cancer* or tumor* or carcinoma* or neoplasm*).tw. (1573780)

103 or/101-102 (2505578)

104 exp Diabetes Mellitus, Type 2/ (63869)

105 exp Insulin Resistance/ (38231)

106 ((typ* 2 or typ* ii) adj diabet*).tw. (51164)

107 impaired glucose toleranc*.tw. (6845)

108 glucose intoleranc*.tw. (5714)

109 insulin resistanc*.tw. (36244)

110 (MODY or NIDDM or T2DM or DM 2).tw. (10504)

111 ((non insulin* or noninsulin*) adj2 depend*).tw. (11937)

112 (non insulin?depend* or noninsulin?depend*).tw. (18)

113 ((keto restist* or non keto* or nonketo*) adj2 diabet*).tw. (346)

114 ((adult* or matur* or late or slow or stabl*) adj2 diabet*).tw. (5486)

115 (insulin defic* adj2 relativ*).tw. (126)

116 plur?metabolic* syndrome*.tw. (32)

117 or/104-115 (128394)

118 exp diabetes insipidus/ (6512)

119 diabet* insipidus.tw. (6199)

120 or/118-119 (8185)

121117 not $120(128330)$

122 Interleukin-6/ (35767)

123 exp receptors, interleukin-6/ (2773)

124 c-reactive protein/ (22323)

125 tumor necrosis factor-alpha/ (79154)

126 Cytokines/ (79501)

127 exp lymphocytes/ (390817)

128 (interleukin 6 or IL 6 or IL6).tw. (58213)

129 (interleukin* adj2 (b or hp1)).tw. (227)

130 ((plasmacytoma or hybridoma) adj2 growth factor*).tw. (97)

131 (b cell adj2 (differentiat* or stimulat*)).tw. (4462)

132 (hepatocyte adj2 stimulat*).tw. (485)

133 ((beta2 or beta 2) adj2 interferon*).tw. (133)

134 (hepatocyte adj2 stimulat*).tw. (485)

135 (b adj lymphocyte*).tw. (25416)

136 (BSF?2 or IFN?beta?2 or MGI?2).tw. (56)

137 (BSF 2 or IFN beta 2 or MGI 2).tw. (242)

138 (myeloid adj3 protein).tw. (449)

139 ((26k or $26 \mathrm{k})$ adj2 protein*).tw. (36)

140 ((((il6 or il 6) adj soluble*) or (sil6r or sil $6 \mathrm{r}$ or il6r or il $6 \mathrm{r}$ or interleukin 6 receptor)) adj4 protein*).tw. (56)

141 (hsCRP or CRP).tw. (20078)

142 cd126.tw. (51) 
143 (high sensitiv* adj3 c reactive protein*).tw. (3292)

144 cachectin*.tw. (447)

145 (Tnfalpha or tnf alpha*).tw. (70756)

146 tumor necrosis*.tw. (69922)

147 Tnf superfamily*.tw. (493)

148 (lymphocyte* or ((lymphoid* or killer) adj2 cell*)).tw. (282046)

149 or/122-148 (675867)

150 exp Kidney Diseases/ (358584)

151 exp Renal Circulation/ (11422)

152 (((kidney* or renal*) adj2 (calculi or calculus or stone*)) or nephrolithiasis).tw. (9918)

153 ((kidney* or renal*) adj2 (disease* or function*)).tw. (114942)

154 (renal adj3 (flow* or circulat*)).tw. (13708)

155 or/150-154 (418863)

156 exp Muscle Strength/ (10755)

157 Muscle Fatigue/ (4587)

158 exp Physical Endurance/ (19718)

159 exp Exercise/ (54191)

160 Physical fitness/ (18227)

161 exp Motor Activity/ (93817)

162 ((muscle or muscular) adj2 (strength* or fatigue* or weak*)).tw. (22245)

163 (physical* adj2 (fitness or exercise* or active or activity or endur*)).tw. (50835)

164 ((train* or exercise*) adj2 endur*).tw. (6383)

165 or/156-164 (218608)

166 Mortality/ (30837)

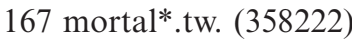

168 ((fatalit* or death*) adj2 rate*).tw. (21676)

169 (excess adj2 mortalit*).tw. (3980)

170 or/166-169 (382939)

171 exp Lactation/ (29877)

172 Milk, human/ (13700)

173 breast feeding/ (22118)

174 lactation*.tw. (23492)

175 (milk adj2 (human* or breast*)).tw. (13617)

176 (breast feed* or breastfeed*).tw. (19668)

177 or/171-176 (74168)

17818 and 29 (2069)

17918 and $38(4390)$

18018 and 45 (2751)

18118 and 51 (1153)

18218 and 65 (3577)

18318 and 72 (1449)

18418 and 89 (12410)

18518 and 94 (9635)

18618 and 100 (3007)

18718 and 103 (3541)

18818 and $121(863)$

18918 and $149(2860)$

19018 and 155 (2096)

19118 and 165 (1243)

19218 and 170 (901)

19318 and 177 (2680)

194 or/178-193 (26444)

195 limit 194 to (humans and $\mathrm{yr}=$ "2000-Current") (6022)

196 limit 195 to English language (5632)

197 limit 196 to "reviews (sensitivity)" (3153) 


\section{Appendix 3}

Excluded full text papers

Article

Reason for exclusion

Andrews, R. D., D. A. MacLean, et al. (2006). "Protein intake for skeletal muscle hypertrophy with

Intervention with soy protein isolate resistance training in seniors." International Journal of Sport Nutrition and Exercise Metabolism 16(4): 362-372

Bell, J. and S. J. Whiting (2002). "Elderly women need dietary protein to maintain bone mass." Nutrition Review Reviews 60(I0:Pt:I): t-4I

Berndt, S. I., H. B. Carter, et al. (2002). "Calcium intake and prostate cancer risk in a long-term aging study: Main focus on calcium the Baltimore Longitudinal Study of Aging." Urology 60(6): III8-II23

Berrut, G., A. M. Favreau, et al. (2002). "Estimation of calorie and protein intake in aged patients: validation of Patients a method based on meal portions consumed.” Journals of Gerontology Series A-Biological Sciences and Medical Sciences 57(I): M52-M56

Biolo, G., B. Ciocchi, et al. (2007). "Calorie restriction accelerates the catabolism of lean body mass during Not elderly 2 wk of bed rest." American Journal of Clinical Nutrition 86(2): 366-372

Bischoff Ferrari, H. A. (2009). "Validated treatments and therapeutic perspectives regarding nutritherapy." Review Journal of Nutrition, Health and Aging 13(8): 737-74I

Boirie, Y. (2009). "Physiopathological mechanism of sarcopenia." Journal of Nutrition, Health and Aging I3(8): Review 717-723

Bonnefoy, M., C. Cornu, et al. (2003). "The effects of exercise and protein-energy supplements on body composition and muscle function in frail elderly individuals: a long-term controlled randomized study." British Journal of Nutrition 89(5): 731-739

Bonnefoy, M., T. Constans, et al. (2000). "Influence of nutrition and physical activity on muscle in the very elderly." Presse Medicale 29(39): 2177-2182

Bossingham, M. J., N. S. Carnell, et al. (2005). "Water balance, hydration status, and fat-free mass hydration in Not protein younger and older adults." American Journal of Clinical Nutrition 8I(6): I342-1350

Campbell, W. W. (2007). "Synergistic use of higher-protein diets or nutritional supplements with resistance Review training to counter sarcopenia." Nutrition Reviews 65(9): 416-422

Campbell, W. W. and H. J. Leidy (2007). "Dietary protein and resistance training effects on muscle and body Review composition in older persons." Journal of the American College of Nutrition 26(6): 696S-703S

Campbell, W. W., M. D. Haub, et al. (2009). "Resistance training preserves fat-free mass without impacting Training after weight loss changes in protein metabolism after weight loss in older women." Obesity 17(7): 1332-1339

Candow, D. G. and P. D. Chilibeck (2008). "Timing of creatine or protein supplementation and resistance Review training in the elderly." Applied Physiology, Nutrition, and Metabolism =Physiologie Appliquee, Nutrition et Metabolisme 33(I): 184-190

Caso, G., J. Feiner, et al. (2007). "Response of albumin synthesis to oral nutrients in young and elderly subjects." American Journal of Clinical Nutrition 85(2): 446-45I

Chaput, J. P., C. Lord, et al. (2007). "Relationship between antioxidant intakes and class I sarcopenia in elderly Cross-sectional men and women." Journal of Nutrition, Health and Aging II (4): 363-369

Charlton, K. E. (2002). "Eating well: ageing gracefully!” Asia Pacific Journal of Clinical Nutrition II: Suppl-I7 Review

Chernoff, R. (2004). "Protein and older adults." Journal of the American College of Nutrition 23(6:Suppl): Review Suppl-630S

Chevalier, S., E. D. Goulet, et al. (20I I). "Protein anabolic responses to a fed steady state in healthy aging." Short-term Journals of Gerontology Series A Biological Sciences \& Medical Sciences 66(6): 68I-688

Chevalier, S., R. Gougeon, et al. (2003). "Frailty amplifies the effects of aging on protein metabolism: role of Frailty protein intake." American Journal of Clinical Nutrition 78(3): 422-429

Chevalley, T., P. Hoffmeyer, et al. (2010). "Early serum IGF-I response to oral protein supplements in elderly Protein supplements, patients women with a recent hip fracture." Clinical Nutrition 29(I): 78-83

Coin, A., E. Perissinotto, et al. (2008). "Predictors of low bone mineral density in the elderly: the role of Cross-sectional dietary intake, nutritional status and sarcopenia." European Journal of Clinical Nutrition 62(6): 802-809

Darmon, P., M. J. Kaiser, et al. (2010). "Restrictive diets in the elderly: never say never again?" Clinical Review Nutrition 29(2): 170-174

Davies, K. M., R. P. Heaney, et al. (2002). "Decline in muscle mass with age in women: a longitudinal study using Not elderly an indirect measure.” Metabolism: Clinical and Experimental 5I(7): 935-939 
Davy, K. P., T. Horton, et al. (200I). "Regulation of macronutrient balance in healthy young and older men." Cross-sectional International Journal of Obesity and Related Metabolic Disorders: Journal of the International Association for the Study of Obesity 25(10): 1497-1502

Dillon, E. L., M. Sheffield-Moore, et al. (2009). "Amino acid supplementation increases lean body mass, basal Amino acid supplementation muscle protein synthesis, and insulin-like growth factor-I expression in older women." Journal of Clinical Endocrinology and Metabolism 94(5): 1630-1637

DiMaria-Ghalili, R. A. and E. Amella (2005). "Nutrition in older adults." American Journal of Nursing 105(3): Review 40-50

Dorrens, J. and M. J. Rennie (2003). "Effects of ageing and human whole body and muscle protein turnover." Review Scandinavian Journal of Medicine and Science in Sports I3(I): 26-33

Dreyer, H. C. and E. Volpi (2005). "Role of protein and amino acids in the pathophysiology and treatment of Review sarcopenia." Journal of the American College of Nutrition 24(2): I40S-I45S

Durham, W. J., S. L. Casperson, et al. (2010). "Age-related anabolic resistance after endurance-type exercise in Amino acid infusion healthy humans." FASEB Journal 24(10): 4II7-4I27

Esmarck, B., J. L. Andersen, et al. (200I). "Timing of postexercise protein intake is important for muscle hypertrophy with resistance training in elderly humans." Journal of Physiology 535(Pt: I): I-I I

Evans, W. J. (2002). "Effects of exercise on senescent muscle." Clinical Orthopaedics and Related Research(403:Suppl): Suppl-20

Evans, W. J. (2004). "Protein nutrition, exercise and aging." Journal of the American College of Nutrition Review 23(6:Suppl): Suppl-609S

Ferrando, A. A., D. Paddon-Jones, et al. (2010). "EAA supplementation to increase nitrogen intake improves muscle function during bed rest in the elderly." Clinical Nutrition 29(I): 18-23

Freeman, S. L., L. Fisher, et al. (2010). "Dairy proteins and the response to pneumovax in senior citizens: a randomized, double-blind, placebo-controlled pilot study." Annals of the New York Academy of Sciences I190: 97-103

Fujita, S. and E. Volpi (2006). "Amino acids and muscle loss with aging." Journal of Nutrition I36(I:Suppl): Suppl-80S

Fukagawa, N. K. and R. A. Galbraith (2004). "Advancing age and other factors influencing the balance between Review amino acid requirements and toxicity." Journal of Nutrition 134(6:Suppl): Suppl-I574S

Gaffney-Stomberg, E., K. L. Insogna, et al. (2009). "Increasing dietary protein requirements in elderly people Review for optimal muscle and bone health." Journal of the American Geriatrics Society 57(6): 1073-1079

Gaillard, C., E. Alix, et al. (2008). "Are elderly hospitalized patients getting enough protein?" Journal of the American Geriatrics Society 56(6): 1045-1049

Genaro Pde, S. and L. A. Martini (2010). "Effect of protein intake on bone and muscle mass in the elderly. [Review]." Nutrition Reviews 68(10): 616-623

Giovannucci, E., M. Pollak, et al. (2003). "Nutritional predictors of insulin-like growth factor I and their relationships to cancer in men." Cancer Epidemiology, Biomarkers and Prevention 12(2): 8489

Gordon, M. M., M. J. Bopp, et al. (2008). "Effects of dietary protein on the composition of weight loss in post-menopausal women." Journal of Nutrition, Health and Aging 12(8): 505-509

Goulet, E. D., C. Lord, et al. (2007). "No difference in insulin sensitivity between healthy postmenopausal women with or without sarcopenia: a pilot study." Applied Physiology, Nutrition, and Metabolism = Physiologie Appliquee, Nutrition et Metabolisme 32(3): 426-433

Greenwood, C. E. (2003). "Dietary carbohydrate, glucose regulation, and cognitive performance in elderly persons." Nutrition Reviews 6I (5:Pt:2): t-74

Guillet, C. and Y. Boirie (2005). "Insulin resistance: a contributing factor to age-related muscle mass loss?" Diabetes and Metabolism 3I: Spec-5S26

Haub, M. D., A. M. Wells, et al. (2005). "Beef and soy-based food supplements differentially affect serum lipoprotein-lipid profiles because of changes in carbohydrate intake and novel nutrient intake ratios in older men who resistive-train." Metabolism: Clinical and Experimental 54(6): 769-774

Hays, N. P., H. Kim, et al. (2009). "Effects of whey and fortified collagen hydrolysate protein supplements on Protein supplement (hydrolysates) nitrogen balance and body composition in older women." Journal of the American Dietetic Association 109(6): 1082-1087 
Appendix 3 (Continued)

Article

Reason for exclusion

Iglay, H. B., J. P. Thyfault, et al. (2007). "Resistance training and dietary protein: effects on glucose tolerance and Not elderly (6I \pm I yr) contents of skeletal muscle insulin signaling proteins in older persons." American Journal of Clinical Nutrition 85(4): 1005-1013

Iglay, H. B., J. W. Apolzan, et al. (2009). "Moderately increased protein intake predominately from egg sources Not elderly (6I \pm I yr) does not influence whole body, regional, or muscle composition responses to resistance training in older people." Journal of Nutrition, Health and Aging I3(2): I08-II4

Ilich, J. Z., R. A. Brownbill, et al. (2003). "Bone and nutrition in elderly women: protein, energy, and calcium as Cross-sectional main determinants of bone mineral density." European Journal of Clinical Nutrition 57(4): 554-565

Jensen, G. L. (2008). "Inflammation: roles in aging and sarcopenia.” Jpen: Journal of Parenteral and Enteral Review Nutrition 32(6): 656-659

Johnson, M. A., J. T. Dwyer, et al. (20II). "Challenges and new opportunities for clinical nutrition interventions Review in the aged." Journal of Nutrition I4I(3): 535-54I

Jordan, L. Y., E. L. Melanson, et al. (2010). "Nitrogen balance in older individuals in energy balance depends on Short-term timing of protein intake.” Journals of Gerontology Series A-Biological Sciences and Medical Sciences 65(10): 1068-1076

Kaluza, J., J. Dolowa, et al. (2005). "Survival and habitual nutrient intake among elderly men." Roczniki Panstwowego Zakladu Higieny 56(4): 36I-370

Kaplan, R. J., C. E. Greenwood, et al. (200I). "Dietary protein, carbohydrate, and fat enhance memory performance in the healthy elderly." American Journal of Clinical Nutrition 74(5): 687-693

Kenny, A. M., K. M. Mangano, et al. (2009). "Soy proteins and isoflavones affect bone mineral density in older women: a randomized controlled trial.” American Journal of Clinical Nutrition $90(\mathrm{I})$ :

$234-242$

Kim, J. S., J. M. Wilson, et al. (2010). "Dietary implications on mechanisms of sarcopenia: roles of protein, Review amino acids and antioxidants.” Journal of Nutritional Biochemistry 2I(I): I-I3

Koopman, R. (201 I). "Dietary protein and exercise training in ageing.” Proceedings of the Nutrition Society Review 70(I): 104-II3

Kukuljan, S., C. A. Nowson, et al. (2009). "Effects of resistance exercise and fortified milk on skeletal muscle Not protein (fortification) mass, muscle size, and functional performance in middle-aged and older men: an I8-mo randomized controlled trial.” Journal of Applied Physiology 107(6): 1864-1873

Kurpad, A. V. and M. Vaz (2000). "Protein and amino acid requirements in the elderly." European Journal of Review Clinical Nutrition 54: Suppl-42

Larsson, S. C., K. Wolk, et al. (2005). "Association of diet with serum insulin-like growth factor I in Cross-sectional middle-aged and elderly men." American Journal of Clinical Nutrition 8I(5): II63-II67

Lim, L. S., L. J. Harnack, et al. (2004). "Vitamin A intake and the risk of hip fracture in postmenopausal women: Not protein the lowa Women's Health Study." Osteoporosis International I5(7): 552-559

Lin, Y. C., J. F. Chiu, et al. (2005). "Bone health status of the elderly in Taiwan by quantitative ultrasound." Asia Pacific Journal of Clinical Nutrition 14(3): 270-277

Longcope, C., H. A. Feldman, et al. (2000). "Diet and sex hormone-binding globulin.” Journal of Clinical Endocrinology and Metabolism 85(I): 293-296

Lord, C., J. P. Chaput, et al. (2007). "Dietary animal protein intake: association with muscle mass index in older women." Journal of Nutrition, Health and Aging I I(5): 383-387

Lucas, M. and C. J. Heiss (2005). "Protein needs of older adults engaged in resistance training: a review." Journal of Aging and Physical Activity 13(2): 223-236

Martin, H., A. Aihie Sayer, et al. (20II). "Does diet influence physical performance in community-dwelling older people? Findings from the Hertfordshire Cohort Study." Age \& Ageing 40(2): 18I-186

Mathus-Vliegen, E. M. (2004). “Old age, malnutrition, and pressure sores: an ill-fated alliance.” Journals of Patients Gerontology Series A-Biological Sciences and Medical Sciences 59(4): 355-360

Mattson, M. P., W. Duan, et al. (200I). "Suppression of brain aging and neurodegenerative disorders by dietary Dietary restriction restriction and environmental enrichment: molecular mechanisms.” Mechanisms of Ageing and Development 122(7): 757-778

McFarlin, B. K., M. G. Flynn, et al. (2006). "Energy restriction with different protein quantities and source: implications for innate immunity." Obesity 14(7): $1211-1218$

Asian population

Cross-sectional

Cross-sectional

Review

Cross-sectional

Energy restriction 
Mercier, S., D. Breuille, et al. (2006). "Methionine kinetics are altered in the elderly both in the basal state and Amino acid metabolism (methionine) after vaccination.” American Journal of Clinical Nutrition 83(2): 29I-298

Miller, G. D. (2010). "Improved nutrient intake in older obese adults undergoing a structured diet and exercise Weight loss program in obesity intentional weight loss program.” Journal of Nutrition, Health and Aging 14(6): 46I-466

Millward, D. J. (2008). "Sufficient protein for our elders?" American Journal of Clinical Nutrition 88(5): $\quad$ Review || |87-I| 88

Morais, J. A., S. Chevalier, et al. (2006). "Protein turnover and requirements in the healthy and frail elderly." Review Journal of Nutrition, Health and Aging 10(4): 272-283

Moriguti, J. C., E. Ferriolli, et al. (2005). "Effects of arginine supplementation on the humoral and innate immune response of older people." European Journal of Clinical Nutrition 59(I2): 1362-1366

Murad, H. and M. P. Tabibian (200I). "The effect of an oral supplement containing glucosamine, amino acids, Supplements minerals, and antioxidants on cutaneous aging: a preliminary study." Journal of Dermatological Treatment I2(I): 47-5I

Nakamura, K., Y. Hori, et al. (2003). "Nutritional covariates of dietary calcium in elderly Japanese women: Japanese results of a study using the duplicate portion sampling method." Nutrition 19(II-12): 922-925

Nakamura, K., Y. Hori, et al. (2004). "Dietary calcium, sodium, phosphorus, and protein and bone metabolism Japanese in elderly Japanese women: a pilot study using the duplicate portion sampling method." Nutrition 20(4): 340-345

Nieves, J. W. (2003). "Calcium, vitamin D, and nutrition in elderly adults." Clinics in Geriatric Medicine 19(2): Review 32I-335

Onambele-Pearson, G. L., L. Breen, et al. (2010). "Influences of carbohydrate plus amino acid supplementation Amino acid supplementation on differing exercise intensity adaptations in older persons: skeletal muscle and endocrine responses." Age 32(2): $125-138$

Oomen, C. M., M. J. van Erk, et al. (2000). "Arginine intake and risk of coronary heart disease mortality in elderly men.” Arteriosclerosis, Thrombosis and Vascular Biology 20(9): 2134-2139

Paddon-Jones, D. and B. B. Rasmussen (2009). "Dietary protein recommendations and the prevention of sarcopenia." Current Opinion in Clinical Nutrition and Metabolic Care I2(I): 86-90

Paddon-Jones, D., K. R. Short, et al. (2008). "Role of dietary protein in the sarcopenia of aging." American Review Journal of Clinical Nutrition 87(5): I562S-I566S

Pfrimer, K., J. S. Marchini, et al. (2009). "Fed state protein turnover in healthy older persons under a usual Short-term protein-rich diet." Journal of Food Science 74(4): HII2-HII5

Pitkanen, H. T., S. S. Oja, et al. (2003). "Serum amino acid concentrations in aging men and women." Amino Acids 24(4): 4|3-42|

Pounis, G. D., S. Tyrovolas, et al. (2010). "Long-term animal-protein consumption is associated with an increased prevalence of diabetes among the elderly: the Mediterranean Islands (MEDIS) study." Diabetes \& Metabolism 36(6 Pt I): 484490

Rennie, M. J. (2009). "Anabolic resistance: the effects of aging, sexual dimorphism, and immobilization on human muscle protein turnover." Applied Physiology, Nutrition, and Metabolism = Physiologie Appliquee, Nutrition et Metabolisme 34(3): 377-38I

Rieu, I., M. Balage, et al. (2006). "Leucine supplementation improves muscle protein synthesis in elderly men Amino acid supplementation independently of hyperaminoacidaemia.” Journal of Physiology 575(Pt:I): I-I5

Risonar, M. G., P. Rayco-Solon, et al. (2009). "Physical activity, energy requirements, and adequacy of dietary Filipino study intakes of older persons in a rural Filipino community." Nutrition Journal 8: 19

Ritz, P. (2000). "Physiology of aging with respect to gastrointestinal, circulatory and immune system changes and their significance for energy and protein metabolism." European Journal of Clinical Nutrition 54: Suppl-5

Ritz, P. (200I). "Factors affecting energy and macronutrient requirements in elderly people." Public Health Nutrition 4(2B): $56 \mathrm{I}-568$

Rodondi, A., P. Ammann, et al. (2009). "Zinc increases the effects of essential amino acids-whey protein supplements in frail elderly." Journal of Nutrition, Health and Aging 13(6): 49I-497

Rolland, Y. and F. Pillard (2009). "Validated treatments and therapeutic perspectives regarding physical activities." Journal of Nutrition, Health and Aging 13(8): 742-745

Review

Review

Zinc and frail elderly

Review 
Appendix 3 (Continued)

Article

Reason for exclusion

Rolland, Y., C. Dupuy, et al. (20II). “Treatment strategies for sarcopenia and frailty. [Review].” Medical Clinics Review of North America 95(3): 427-438

Roubenoff, R. (2000). "Sarcopenia: a major modifiable cause of frailty in the elderly." Journal of Nutrition, Review Health and Aging 4(3): 140-142

Sahyoun, N. R., A. L. Anderson, et al. (2008). "Dietary glycemic index and glycemic load and the risk of type 2 Not focus on protein diabetes in older adults.” American Journal of Clinical Nutrition 87(I): I26-13 I

Sallinen, J., A. Pakarinen, et al. (2006). "Serum basal hormone concentrations and muscle mass in aging women: Not elderly (58 \pm 6 y) effects of strength training and diet." International Journal of Sport Nutrition and Exercise Metabolism 16(3): 316-331

Sallinen, J., A. Pakarinen, et al. (2007). "Dietary intake, serum hormones, muscle mass and strength during strength training in 49-73-year-old men.” International Journal of Sports Medicine 28(I2): $1070-1076$

Scognamiglio, R., A. Avogaro, et al. (2004). "The effects of oral amino acid intake on ambulatory capacity in Amino acid supplementation elderly subjects." Aging-Clinical and Experimental Research 16(6): 443-447

Scognamiglio, R., R. Piccolotto, et al. (2005). "Oral amino acids in elderly subjects: effect on myocardial function and walking capacity." Gerontology 5I(5): 302-308

Scott, D., L. Blizzard, et al. (2010). "Associations between dietary nutrient intake and muscle mass and strength in community-dwelling older adults: the Tasmanian Older Adult Cohort Study." Journal of the American Geriatrics Society 58(II): 2129-2134

Selhub, J., L. C. Bagley, et al. (2000). "B vitamins, homocysteine, and neurocognitive function in the elderly." Not protein American Journal of Clinical Nutrition 7I(2): 6I4S 620S

Sjogren, P., W. Becker, et al. (2010). "Mediterranean and carbohydrate-restricted diets and mortality among Not protein (dietary patterns) elderly men: a cohort study in Sweden.” American Journal of Clinical Nutrition 92(4): 967-974

Solerte, S. B., C. Gazzaruso, et al. (2008). "Nutritional supplements with oral amino acid mixtures increases Amino acid supplementation whole-body lean mass and insulin sensitivity in elderly subjects with sarcopenia." American Journal of Cardiology I0I(IIA): 69E-77E

Song, Y., J. E. Manson, et al. (2004). "A prospective study of red meat consumption and type 2 diabetes in Not protein (food based) middle-aged and elderly women: the women's health study." Diabetes Care 27(9): 2108-21।5

Stookey, J. D., L. S. Adair, et al. (2005). "Do protein and energy intakes explain long-term changes in body Chinese composition?" Journal of Nutrition, Health and Aging 9(I): 5-I7

Strassburg, A., C. Krems, et al. (2004). "Effect of age on plasma homocysteine concentrations in young and Not protein elderly subjects considering serum vitamin concentrations and different lifestyle factors." International Journal for Vitamin and Nutrition Research 74(2): 129-136

Symons, T. B., M. Sheffield-Moore, et al. (2009). "A moderate serving of high-quality protein maximally Short-term stimulates skeletal muscle protein synthesis in young and elderly subjects." Journal of the American Dietetic Association 109(9): 1582-1586

Symons, T. B., S. E. Schutzler, et al. (2007). "Aging does not impair the anabolic response to a protein-rich meal." American Journal of Clinical Nutrition 86(2): 45I-456

Thalacker-Mercer, A. E. and W. W. Campbell (2008). "Dietary protein intake affects albumin fractional Review synthesis rate in younger and older adults equally." Nutrition Reviews 66(2): 91-95

Thalacker-Mercer, A. E., J. C. Fleet, et al. (2007). "Inadequate protein intake affects skeletal muscle transcript Short-term profiles in older humans." American Journal of Clinical Nutrition 85(5): I344-1352

Timmerman, K. L. and E. Volpi (2008). "Amino acid metabolism and regulatory effects in aging." Current Review Opinion in Clinical Nutrition and Metabolic Care II (I): 45-49

Tucker, K. L., et al. (200I). "The acid-base hypothesis: diet and bone in the Framingham Osteoporosis Study." Same data as Hannan et al. 2000 European Journal of Nutrition 40(5): 231-237.

Tyrovolas, S., T. Psaltopoulou, et al. (201I). "Nutrient intake in relation to central and overall obesity status Cross-sectional among elderly people living in the Mediterranean islands: the MEDIS study." Nutrition Metabolism \& Cardiovascular Diseases 2I(6): 438-445

Verdijk, L.B., et al. (2009) "Protein supplementation before and after exercise does not further augment Casein hydrolysate skeletal muscle hypertrophy after resistance training in elderly men." American Journal of Clinical Nutrition $89(2): 608-16$ 
Appendix 3 (Continued)

Article

Reason for exclusion

Verhoeven, S., K. Vanschoonbeek, et al. (2009). "Long-term leucine supplementation does not increase muscle Amino acid supplementation mass or strength in healthy elderly men." American Journal of Clinical Nutrition 89(5): |468-1475

Visser, M., S. B. Kritchevsky, et al. (2005). "Lower serum albumin concentration and change in muscle mass: Se-albumin, not protein the Health, Aging and Body Composition Study." American Journal of Clinical Nutrition 82(3): 53I-537

Visvanathan, R. and I. Chapman (2010). "Preventing sarcopaenia in older people." Maturitas 66(4): 383-388 Review

Volkert, D., K. Kreuel, et al. (2004). "Energy and nutrient intake of young-old, old-old and very-old elderly in Cross-sectional Germany." European Journal of Clinical Nutrition 58(8): 1190-1200

Volpi, E., H. Kobayashi, et al. (2003). "Essential amino acids are primarily responsible for the amino acid Amino acid supplementation stimulation of muscle protein anabolism in healthy elderly adults." American Journal of Clinical Nutrition 78(2): 250-258

Wagner, E. A., G. A. Falciglia, et al. (2007). "Short-term exposure to a high-protein diet differentially affects Short-term glomerular filtration rate but not Acid-base balance in older compared to younger adults." Journal of the American Dietetic Association 107(8): 1404-1408

Walrand, S. (2010). "Ornithine alpha-ketoglutarate: could it be a new therapeutic option for sarcopenia?" Review Journal of Nutrition, Health \& Aging 14(7): 570-577

Walrand, S. and Y. Boirie (2005). "Optimizing protein intake in aging." Current Opinion in Clinical Nutrition Review and Metabolic Care 8(I): 89-94

Walrand, S., C. Guillet, et al. (201 I). "Physiopathological mechanism of sarcopenia." Clinics in Geriatric Review Medicine 27(3): 365-385

Waters, D. L., R. N. Baumgartner, et al. (2000). "Sarcopenia: current perspectives.” Journal of Nutrition, Review Health and Aging 4(3): 133-139

Waters, D. L., R. N. Baumgartner, et al. (2010). "Advantages of dietary, exercise-related, and therapeutic Review interventions to prevent and treat sarcopenia in adult patients: an update." Clinical Interventions In Aging 5: 259-270

Wells, A. M., M. D. Haub, et al. (2003). "Comparisons of vegetarian and beef-containing diets on hematological Vegetarian versus beef diet, not protein indexes and iron stores during a period of resistive training in older men." Journal of the American Dietetic Association 103(5): 594 60I

Wernette, C. M., B. D. White, et al. (2011). "Signaling proteins that influence energy intake may affect Review unintentional weight loss in elderly persons. [Review].” Journal of the American Dietetic Association II I (6): 864873

Wilson, M. M., R. Purushothaman, et al. (2002). "Effect of liquid dietary supplements on energy intake in the Short-term elderly.” American Journal of Clinical Nutrition 75(5): 944-947

Wolfe, R. R., S. L. Miller, et al. (2008). "Optimal protein intake in the elderly.” Clinical Nutrition 27(5): 675-684 Review

Zhu, K., X. Meng, et al. (2298). "The effects of a two-year randomized, controlled trial of whey protein Protein isolate supplementation on bone structure, IGF-I, and urinary calcium excretion in older postmenopausal women.” Journal of Bone \& Mineral Research 26(9): 2298-2306 


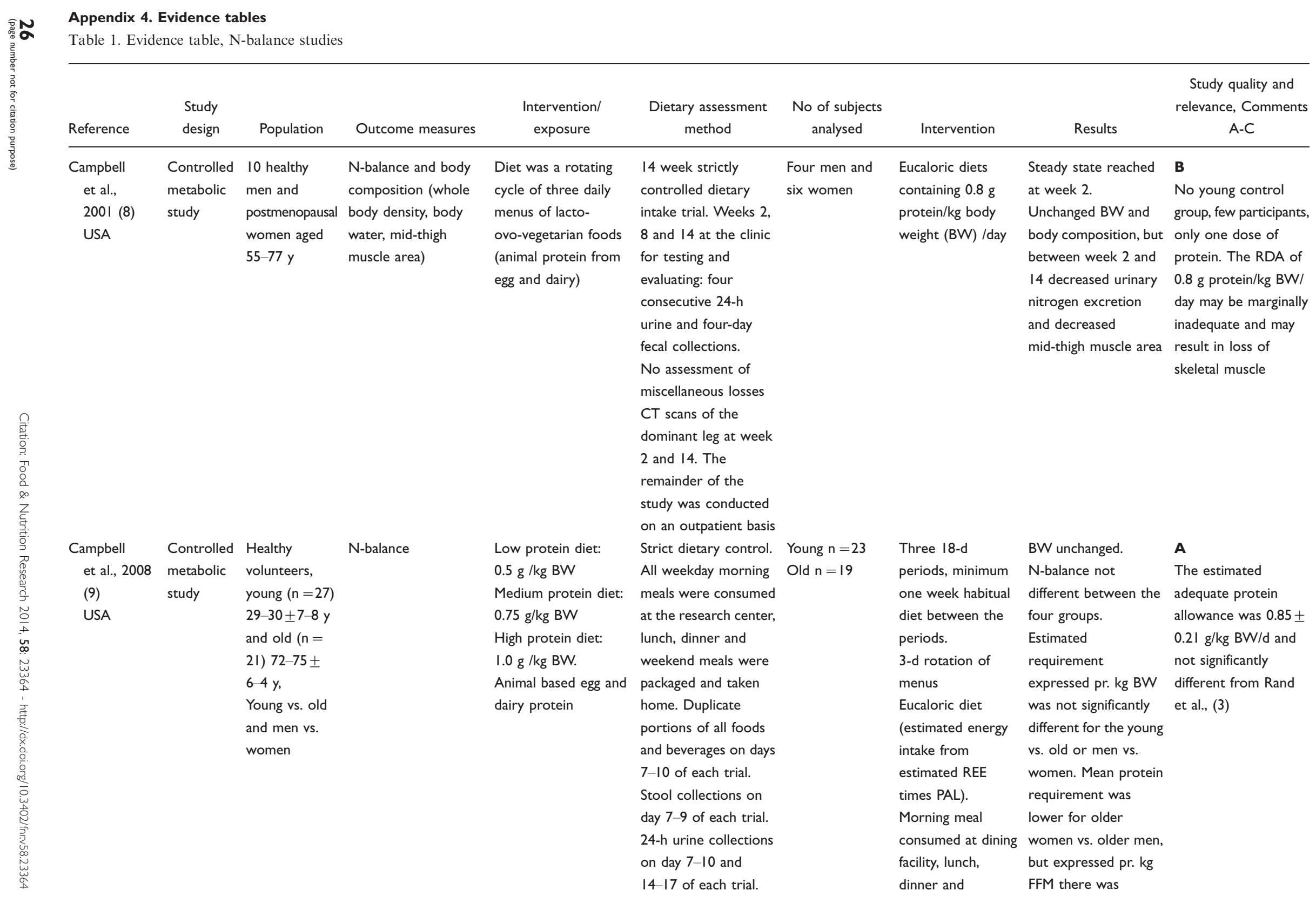




\begin{tabular}{|c|c|c|c|c|c|c|c|c|c|}
\hline Reference & $\begin{array}{l}\text { Study } \\
\text { design }\end{array}$ & Population & Outcome measures & $\begin{array}{l}\text { Intervention/ } \\
\text { exposure }\end{array}$ & $\begin{array}{c}\text { Dietary assessment } \\
\text { method }\end{array}$ & $\begin{array}{c}\text { No of subjects } \\
\text { analysed }\end{array}$ & Intervention & Results & $\begin{array}{c}\text { Study quality and } \\
\text { relevance, Comments } \\
\text { A-C }\end{array}$ \\
\hline & & & & & $\begin{array}{l}\text { Miscellaneous losses } \\
\text { assumed to be } 5 \mathrm{mg} \\
\text { nitrogen } / \mathrm{kg} \mathrm{BW} / \mathrm{d}\end{array}$ & & $\begin{array}{l}\text { weekend meals } \\
\text { were packaged and } \\
\text { taken home }\end{array}$ & $\begin{array}{l}\text { no significant } \\
\text { difference. } \\
\text { For all subjects } \\
\text { combined the } \\
\text { adequate protein } \\
\text { allowance was } \\
\text { estimated to be } \\
0.85 \pm 0.21 \mathrm{~g} / \mathrm{kg} \mathrm{BW} / \mathrm{d}\end{array}$ & \\
\hline $\begin{array}{l}\text { Morse et al., } \\
200 \mathrm{I}(10) \\
\text { USA }\end{array}$ & $\begin{array}{l}\text { Controlled } \\
\text { metabolic } \\
\text { study }\end{array}$ & $\begin{array}{l}12 \text { healthy } \\
\text { women aged } \\
70-81 \text { y }\end{array}$ & $\begin{array}{l}\mathrm{N} \text {-balance, body } \\
\text { composition, resting } \\
\text { metabolic rate }\end{array}$ & $\begin{array}{l}\text { Low protein diet: } \\
0.5 \mathrm{~g} / \mathrm{kg} \text { BW } \\
\text { Medium protein diet: } \\
0.75 \mathrm{~g} / \mathrm{kg} \text { BW High } \\
\text { protein diet: } \\
1.0 \mathrm{~g} / \mathrm{kg} \text { BW. } \\
\text { Animal based egg and } \\
\text { dairy protein. A basal } \\
\text { menu of solid foods } \\
(0.40 \mathrm{~g} / \mathrm{kg} \mathrm{BW}) \\
\text { supplemented with a } \\
\text { protein mixture of } \\
\text { cheese and protein } \\
\text { powder }\end{array}$ & $\begin{array}{l}\text { Strict dietary control. } \\
\text { Duplicate portions of } \\
\text { all foods and } \\
\text { beverages, stool } \\
\text { collections and } 24-\mathrm{h} \\
\text { urine collections on } \\
\text { day } 7-10 \text { and } 14-17 \text { of } \\
\text { each trial. } \\
\text { Miscellaneous losses } \\
\text { assumed to be } 8 \mathrm{mg} \\
\text { nitrogen/kg BW/d }\end{array}$ & 更 & $\begin{array}{l}\text { Three } 18-\mathrm{d} \\
\text { periods, minimum } \\
\text { one week habitual } \\
\text { diet between the } \\
\text { periods. } \\
\text { 3-d rotation of } \\
\text { menus. } \\
\text { Day I: a eucaloric } \\
\text { very low protein } \\
\text { diet (0.18 g/kg BW) } \\
\text { used to enhance } \\
\text { adaption. Morning } \\
\text { meal consumed at } \\
\text { dining facility, lunch, } \\
\text { dinner and weekend } \\
\text { meals were packaged } \\
\text { and taken home }\end{array}$ & $\begin{array}{l}\text { Unchanged BW and } \\
\text { body composition, } \\
\text { Mean adequate } \\
\text { protein allowance was } \\
\text { estimated to be } 0.90 \\
\mathrm{~g} / \mathrm{kg} \mathrm{BW} \text { at week } 2 \\
\text { and } 0.76 \mathrm{~g} / \mathrm{kg} \mathrm{BW} \text { at } \\
\text { week } 3 \text {, but the } \\
\text { urinary nitrogen } \\
\text { excretion decreased } \\
\text { between week } 2 \text { and } \\
3 \text { indicating that a } \\
\text { steady state was not } \\
\text { reached yet. }\end{array}$ & $\begin{array}{l}\text { B } \\
\text { No power calculation. } \\
\text { No young control } \\
\text { group. Women only. } \\
\text { Short-term studies } \\
\text { ( }<2 \text { weeks) may be } \\
\text { inadequate to achieve } \\
\text { N-balance. } \\
\text { The II women are } \\
\text { also included in the } \\
\text { study from } 2008 \text { by } \\
\text { Campbell et al. (9) }\end{array}$ \\
\hline $\begin{array}{l}\text { Rand et al., } \\
2003 \text { (3) }\end{array}$ & $\begin{array}{l}\text { Meta- } \\
\text { analysis }\end{array}$ & $\begin{array}{l}19 \text { balance } \\
\text { studies among } \\
\text { healthy } \\
\text { persons }\end{array}$ & N-balance & & $\begin{array}{l}\text { Controlled nitrogen } \\
\text { (protein) intake. } \\
\text { Measured urine and } \\
\text { faeces, correction } \\
\text { for dermal and } \\
\text { miscellaneous losses. } \\
\text { At least } 3 \text { test protein } \\
\text { intakes, given for } \\
\text { 10-14 days, urinary } \\
\text { and faucal excretion }\end{array}$ & $\mathrm{N}=235$ & & $\begin{array}{l}\text { The median estimated } \\
\text { protein requirement } \\
\text { of good quality } \\
\text { protein: } 0.66 \mathrm{~g} / \mathrm{kg} \\
\mathrm{BW} / \mathrm{d} \text { and the } \\
\text { estimated RDA: } 0.83 \\
\mathrm{~g} / \mathrm{kg} \mathrm{BW} / \mathrm{d} \\
\text { No differences for } \\
\text { adult age groups, sex } \\
\text { or protein source }\end{array}$ & $\begin{array}{l}\text { B } \\
\text { Not sufficient power } \\
\text { to detect possible } \\
\text { differences between } \\
\text { e.g. sex and age } \\
\text { groups. Only one } \\
\text { study with elderly } \\
\text { available in the } \\
\text { analysis. Data suggest } \\
\text { a possible age }\end{array}$ \\
\hline
\end{tabular}


Appendix 4 (Continued)

\begin{tabular}{|c|c|c|c|c|c|c|c|c|c|}
\hline Reference & $\begin{array}{l}\text { Study } \\
\text { design }\end{array}$ & Population & Outcome measures & $\begin{array}{l}\text { Intervention/ } \\
\text { exposure }\end{array}$ & $\begin{array}{l}\text { Dietary assessment } \\
\text { method }\end{array}$ & $\begin{array}{c}\text { No of subjects } \\
\text { analysed }\end{array}$ & Intervention & Results & $\begin{array}{l}\text { Study quality and } \\
\text { relevance, Comments } \\
\text { A-C }\end{array}$ \\
\hline & & & & & $\begin{array}{l}\text { data for, the last } 5 \mathrm{~d} \text {, } \\
\text { eucaloric diet studies } \\
\text { and a adaption period } \\
\approx 5 \mathrm{~d} \text {. }\end{array}$ & & & & $\begin{array}{l}\text { difference in nitrogen } \\
\text { utilization that needs } \\
\text { to be further explored }\end{array}$ \\
\hline $\begin{array}{l}\text { Walrand et al., } \\
2009 \text { (I I) } \\
\text { USA }\end{array}$ & $\begin{array}{l}\text { Controlled } \\
\text { study } \\
\text { Single- } \\
\text { blinded }\end{array}$ & $\begin{array}{l}\text { I0 healthy } \\
\text { young } 24 \pm 1 \text { y } \\
(5 \text { men }) \\
\text { and } \\
10 \text { old } 70 \pm 2 \text { y } \\
(5 \text { men) } \\
\text { volunteers }\end{array}$ & $\begin{array}{l}\mathrm{N} \text {-balance, glomerular } \\
\text { filtration rate (GFR), } \\
\text { Muscle synthesis }\end{array}$ & $\begin{array}{l}\text { High protein (HP): } 3.0 \\
\mathrm{~g} / \mathrm{kg} \text { FFM and usual } \\
\text { protein (UP): } 1.5 \mathrm{~g} / \mathrm{kg} \\
\text { fat free mass (FFM) }\end{array}$ & $\begin{array}{l}\text { All food was prepared } \\
\text { at the metabolic ward. } \\
24 \text {-h urine collection } \\
\text { at the end of each } \\
\text { I0-d trial. No stool } \\
\text { collections and no } \\
\text { estimate for } \\
\text { miscellaneous losses. }\end{array}$ & 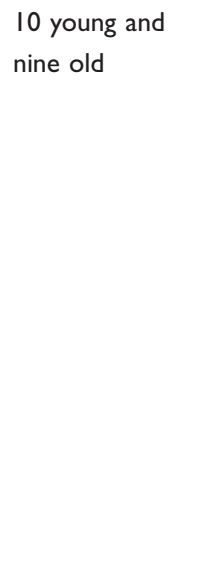 & $\begin{array}{l}\text { I0 days of HP } \\
\text { (Young: } 2.08 \pm 0.07 \\
\text { g/kg BW and old: } \\
1.79 \pm 0.1 \mathrm{~g} / \mathrm{kg} \mathrm{BW)} \\
\text { or } \\
\text { UP (young: } 1.04 \pm \\
0.03 \mathrm{~g} / \mathrm{kg} \mathrm{BW,} \mathrm{and} \\
\text { old } 0.89 \pm 0.05 \mathrm{~g} / \mathrm{kg} \\
\mathrm{BW} \text { ) protein diets } \\
\text { in a cross-over } \\
\text { design, separated } \\
\text { by } 2-8 \text { weeks }\end{array}$ & $\begin{array}{l}\text { Unchanged body } \\
\text { weight. N-balance and } \\
\text { muscle protein } \\
\text { synthesis did not } \\
\text { differ with age. GFR } \\
\text { was lower in older } \\
\text { participants and they } \\
\text { had a lesser increase } \\
\text { in GFR during the HP } \\
\text { diet corresponding to } \\
77 \% \text { of younger } \\
\text { people at the UP and } \\
58 \% \text { of younger } \\
\text { people during HP }\end{array}$ & $\begin{array}{l}\text { B } \\
\text { Short-term, but } \\
\text { relevant because of } \\
\text { the high protein } \\
\text { intake. No age } \\
\text { related difference in } \\
\mathrm{N} \text {-balance but } \\
\text { concern about an HP } \\
\text { diet corresponding to } \\
\text { ca. } 24 \mathrm{E} \% \text { in the elderly } \\
\text { because of potential } \\
\text { adverse effect on the } \\
\text { kidney function }\end{array}$ \\
\hline
\end{tabular}




\section{Appendix 4. Evidence tables}

Table 2. Evidence table, protein and body composition

\begin{tabular}{|c|c|c|c|c|c|c|c|c|c|c|c|c|}
\hline Reference & $\begin{array}{l}\text { Study } \\
\text { design }\end{array}$ & Population & $\begin{array}{l}\text { Outcome } \\
\text { measures }\end{array}$ & $\begin{array}{l}\text { Intervention/ } \\
\text { exposure }\end{array}$ & $\begin{array}{l}\text { Time between } \\
\text { baseline } \\
\text { exposure and } \\
\text { outcome } \\
\text { assessment }\end{array}$ & $\begin{array}{c}\text { Dietary } \\
\text { assessment } \\
\text { method }\end{array}$ & $\begin{array}{c}\text { No of subjects } \\
\text { analysed }\end{array}$ & Intervention & $\begin{array}{l}\text { Follow-up } \\
\text { period, } \\
\text { drop-out } \\
\text { rate }\end{array}$ & Results & $\begin{array}{l}\text { Confounders } \\
\text { adjusted for }\end{array}$ & $\begin{array}{l}\text { Study quality } \\
\text { and relevance, } \\
\text { Comments } \\
\text { A-C }\end{array}$ \\
\hline $\begin{array}{l}\text { Castaneda } \\
\text { et al., } \\
2000 \\
(12) \\
\text { USA }\end{array}$ & $\mathrm{RCT}$ & $\begin{array}{l}12 \text { healthy } \\
\text { women, 66-79 } \\
\text { y, sedentary to } \\
\text { moderately } \\
\text { active }\end{array}$ & $\begin{array}{l}\text { Muscle } \\
\text { fiber } \\
\text { cross- } \\
\text { sectional area } \\
\text { (CSA), } \\
\text { Muscle mass } \\
\text { (estimated } \\
\text { assuming I8.5 } \\
\text { kg muscle/g } \\
\text { urinary } \\
\text { creatinine } \\
\text { from 6-urine } \\
\text { collections), } \\
\text { IGF-I }\end{array}$ & $\begin{array}{l}\text { Marginal } \\
\text { protein diet: } \\
0.45 \mathrm{~g} / \mathrm{kg} \mathrm{BW} \\
(\approx 6 \mathrm{E} \%) \\
\text { Adequate } \\
\text { protein diet: } \\
0.92 \mathrm{~g} / \mathrm{kg} \mathrm{BW} \\
(\approx 13 \mathrm{E} \%)\end{array}$ & 10 weeks & $\begin{array}{l}\text { All food was } \\
\text { provided }\end{array}$ & 12 & $\begin{array}{l}\text { 3-day baseline } \\
\text { milk-based } \\
\text { meat-free diet } \\
\text { containing } 1.2 \\
\mathrm{~g} \text { protein } / \mathrm{kg} \\
\mathrm{BW} \text { and then } \\
\text { randomized } \\
\text { to a weight- } \\
\text { maintaining } \\
\text { (eucaloric) } \\
\text { diet with } \\
\text { marginal or } \\
\text { adequate } \\
\text { protein. } \\
\text { No exercise } \\
\text { training }\end{array}$ & & $\begin{array}{l}\text { Marginal protein } \\
\text { intake resulted } \\
\text { in a decrease in } \\
\text { muscle mass } \\
\text { from } 17 \pm 0.9 \mathrm{~kg} \\
\text { to } 14.7 \pm 0.8 \mathrm{~kg} \\
\text { and decreased } \\
\text { muscle mass } \\
\text { fiber CSA (type } \\
\text { I fibers) and } \\
\text { IGF-I, while the } \\
\text { adequate intake } \\
\text { resulted in } \\
\text { increased fiber } \\
\text { CSA (type I } \\
\text { fibers) and IGF-I }\end{array}$ & Energy intake & $\begin{array}{l}\text { B } \\
\text { Small study, } \\
\text { women } \\
\text { only, no } \\
\text { information } \\
\text { about habitual } \\
\text { diet }\end{array}$ \\
\hline $\begin{array}{l}\text { Houston } \\
\text { et al., } \\
2008 \\
\text { (I3) } \\
\text { USA }\end{array}$ & $\begin{array}{l}\text { Prospective } \\
\text { cohort }\end{array}$ & $\begin{array}{l}2,732 \\
\text { community- } \\
\text { dwelling white } \\
\text { and black, } \\
70-79 \text { y in the } \\
\text { Health, Aging, } \\
\text { and Body } \\
\text { Composition } \\
\text { (Health ABC) } \\
\text { Study. }\end{array}$ & $\begin{array}{l}\text { Body comp } \\
\text { (DXA), } \\
\text { Lean mass } \\
\text { (LM) and } \\
\text { appendicular } \\
\text { LM (aLM) }\end{array}$ & $\begin{array}{l}\text { I. Protein } \\
\text { intake ( } \mathrm{E} \% \text { and } \\
\mathrm{g} / \text { day) in } \\
\text { quintiles. } \\
\text { 2. Vegetable } \\
\text { vs. animal } \\
\text { protein }\end{array}$ & & $\begin{array}{l}\text { FFQ } 108 \\
\text { items, } \\
\text { developed } \\
\text { specifically for } \\
\text { the study, but } \\
\text { no information } \\
\text { about } \\
\text { validation. } \\
\text { Exclusion of } \\
\text { implausible } \\
\text { energy } \\
\text { intakes: <500 } \\
\text { kcal/d or } \\
>3500 \mathrm{kcal} / \mathrm{d}\end{array}$ & $\begin{array}{l}2,066,74 y, \\
53 \% \\
\text { Caucasians }\end{array}$ & $\begin{array}{l}\text { Mean protein } \\
\text { intake } 0.9 \mathrm{~g} / \mathrm{kg} \\
\text { BW/d, mean } \\
\text { loss of LM } \\
0.68 \pm 1.9 \mathrm{~kg}\end{array}$ & 3 year & $\begin{array}{l}\text { Highest } Q 5 \\
(\approx 19 \mathrm{E} \%) \text { of } \\
\text { protein intake } \\
\text { lost } 40 \% \text { less LM } \\
\text { and aLM } \\
\text { compared to the } \\
\text { lowest } Q \\
\text { ( } \approx 11 \mathrm{E} \%) \\
\text { Vegetable } \\
\text { protein did not } \\
\text { relate to loss of } \\
\text { LM. } \\
\text { No difference in } \\
\text { loss of LM }\end{array}$ & $\begin{array}{l}\text { age, sex, race, } \\
\text { study site, } \\
\text { energy intake, } \\
\text { LM or aLM, } \\
\text { height, } \\
\text { smoking, } \\
\text { alcohol, } \\
\text { physical } \\
\text { activity, } \\
\text { prevalent } \\
\text { disease (DM, } \\
\text { CVD, cancer, } \\
\text { COPD, } \\
\text { steroids, }\end{array}$ & B \\
\hline
\end{tabular}


Appendix 4 (Continued)

\begin{tabular}{|c|c|c|c|c|c|c|c|c|c|c|c|c|}
\hline Reference & $\begin{array}{l}\text { Study } \\
\text { design }\end{array}$ & Population & $\begin{array}{l}\text { Outcome } \\
\text { measures }\end{array}$ & $\begin{array}{l}\text { Intervention/ } \\
\text { exposure }\end{array}$ & $\begin{array}{l}\text { Time between } \\
\text { baseline } \\
\text { exposure and } \\
\text { outcome } \\
\text { assessment }\end{array}$ & $\begin{array}{l}\text { Dietary } \\
\text { assessment } \\
\text { method }\end{array}$ & $\begin{array}{c}\text { No of subjects } \\
\text { analysed }\end{array}$ & Intervention & $\begin{array}{l}\text { Follow-up } \\
\text { period, } \\
\text { drop-out } \\
\text { rate }\end{array}$ & Results & $\begin{array}{l}\text { Confounders } \\
\text { adjusted for }\end{array}$ & $\begin{array}{l}\text { Study quality } \\
\text { and relevance, } \\
\text { Comments } \\
\text { A-C }\end{array}$ \\
\hline $\begin{array}{l}\text { Meng } \\
\text { et al., } \\
2009 \\
(14) \\
\text { Australia }\end{array}$ & $\begin{array}{l}\text { Prospective } \\
\text { cohort }\end{array}$ & $\begin{array}{l}\text { I,I69 out of } \\
\text { I,500 } \\
\text { community- } \\
\text { dwelling } \\
\text { women } \\
(70-85 \text { y) did } \\
5 \text { years } \\
\text { follow-up and } \\
\text { of these } 906 \\
\text { had a whole } \\
\text { body DXA }\end{array}$ & $\begin{array}{l}\text { Lean mass, } \\
\mathrm{aLM} \text {, }\end{array}$ & $\begin{array}{l}\text { Tertiles of } \\
\text { protein intake } \\
\text { in g/day }\end{array}$ & & $\begin{array}{l}\text { FFQ } \\
\text { Over the last } \\
\text { I2-month } \\
\text { period. No } \\
\text { information } \\
\text { about } \\
\text { validation }\end{array}$ & $862,75 \pm 3$ y & $\begin{array}{l}\text { Mean protein } \\
\text { intake } 1.2 \mathrm{~g} / \mathrm{kg} \\
\text { BW/d or } 19 \\
\text { E\% } \\
\text { TI: } 0.84 \mathrm{~g} / \mathrm{kg} \\
\mathrm{BW} \text { or } 18 \mathrm{E} \% \\
\text { T3: }>1.6 \mathrm{~g} / \mathrm{kg} \\
\mathrm{BW} \text { or } 20 \mathrm{E} \%\end{array}$ & 5 year & $\begin{array}{l}\text { between } \\
\text { quintiles among } \\
\text { the subgroup } \\
\text { ( } 49.5 \%) \text { of } \\
\text { weight stable } \\
\text { participants. } \\
\text { Top tertile } \\
\text { protein intake } \\
\text { had } \sim 5 \% \text { higher } \\
\text { LM/aLM } \\
\text { compared to the } \\
\text { lowest }\end{array}$ & $\begin{array}{l}\text { Age, height, } \\
\text { energy intake, } \\
\text { physical } \\
\text { activity }\end{array}$ & $\begin{array}{l}\text { C } \\
\text { Part of a } \\
\text { prospective } \\
\text { randomized } \\
\text { controlled } \\
\text { cohort trial of } \\
\text { supplemental } \\
\text { calcium to } \\
\text { prevent } \\
\text { fractures. } \\
\text { No DXA at } \\
\text { start } \\
\text { Underreporting } \\
\text { in lowest } \\
\text { tertile of } \\
\text { protein intake } \\
\text { (energy intake } \\
\approx 5.3 \mathrm{MJ} \text { ) }\end{array}$ \\
\hline
\end{tabular}


Appendix 4. Evidence tables

Table 3. Evidence table, protein and bone health

\begin{tabular}{|c|c|c|c|c|c|c|c|c|c|c|c|c|}
\hline Reference & $\begin{array}{l}\text { Study } \\
\text { design }\end{array}$ & Population & $\begin{array}{l}\text { Outcome } \\
\text { measures }\end{array}$ & $\begin{array}{l}\text { Intervention/ } \\
\text { exposure }\end{array}$ & $\begin{array}{c}\text { Time between } \\
\text { baseline } \\
\text { exposure and } \\
\text { outcome } \\
\text { assessment }\end{array}$ & $\begin{array}{c}\text { Dietary } \\
\text { assessment } \\
\text { method }\end{array}$ & $\begin{array}{c}\text { No of } \\
\text { subjects } \\
\text { analysed }\end{array}$ & Intervention & $\begin{array}{l}\text { Follow-up } \\
\text { period, } \\
\text { drop-out } \\
\text { rate }\end{array}$ & Results & $\begin{array}{l}\text { Confounders } \\
\text { adjusted for }\end{array}$ & $\begin{array}{l}\text { Study quality } \\
\text { and relevance, } \\
\text { Comments } \\
\text { A-C }\end{array}$ \\
\hline $\begin{array}{l}\text { Dawson- } \\
\text { Hughes } \\
\text { and } \\
\text { Harris, } \\
2002 \text { (18) } \\
\text { USA }\end{array}$ & $\mathrm{RCT}$ & $\begin{array}{l}389 \text { men and } \\
\text { women aged } \\
\geq 65 \mathrm{y}\end{array}$ & $\begin{array}{l}\text { Bone loss } \\
\text { (BMD every } \\
6 \text { months at } \\
\text { femoral neck, } \\
\text { spine and } \\
\text { total body) }\end{array}$ & $\begin{array}{l}500 \mathrm{mg} \text { Calcium } \\
\text { and I7.5 } \mu \mathrm{g} \\
\text { vitamin D or } \\
\text { placebo and in } \\
\text { combination } \\
\text { with habitual } \\
\text { protein intake } \\
\text { (total, animal } \\
\text { and vegetable) } \\
\text { assessed at } 18 \\
\text { month visit and } \\
\text { expressed as E\% } \\
\text { in tertiles }\end{array}$ & & $\begin{array}{l}\text { I26-item FFQ } \\
\text { (Willet, } \\
\text { version 1988) } \\
\text { administered } \\
\text { on site and } \\
\text { reviewed for } \\
\text { completeness } \\
\text { by staff. } \\
\text { Information } \\
\text { about } \\
\text { validation } \\
\text { only as } \\
\text { several } \\
\text { references }\end{array}$ & 342 & 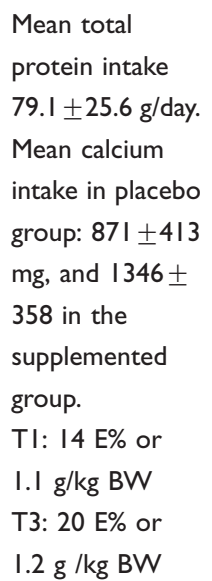 & $3 y$ & $\begin{array}{l}\text { In the } \\
\text { intervention } \\
\text { group (with } \\
\text { calcium and } \\
\text { vitamin } D \text { ) the } \\
\text { highest tertile } \\
\text { was associated } \\
\text { with less total } \\
\text { body BMD loss } \\
(P=0.046 \text { ) and } \\
\text { at femoral neck } \\
(P=0.00 I) \\
\text { compared to } \\
\text { lowest tertile }\end{array}$ & $\begin{array}{l}\text { Sex, age, BW, } \\
\text { energy intake, } \\
\text { dietary } \\
\text { calcium } \\
\text { intake, } \\
\text { (physical } \\
\text { activity, } \\
\text { smoking) }\end{array}$ & $\begin{array}{l}\text { B } \\
\text { Positive effect } \\
\text { of protein } \\
\text { provided high } \\
\text { calcium and } \\
\text { vitamin D } \\
\text { intake. } \\
\text { Habitual intake } \\
\text { of calcium and } \\
\text { vitamin D } \\
\text { almost } \\
\text { according to } \\
\text { recommenda- } \\
\text { tions. }\end{array}$ \\
\hline $\begin{array}{l}\text { Dawson- } \\
\text { Hughes } \\
\text { et al., } \\
2004 \\
\text { (I5) } \\
\text { USA }\end{array}$ & $\mathrm{RCT}$ & $\begin{array}{l}33 \text { men and } \\
\text { women aged } \\
\geq 50 \mathrm{y} \text {. } \\
\text { Usual diet of } \\
\text { protein = } \\
0.85 \mathrm{~g} / \mathrm{kg} \mathrm{BW} \\
\text { or calcium } \\
\text { intake } \\
<700 \mathrm{mg}\end{array}$ & $\begin{array}{l}\text { Urinary } \\
\text { calcium } \\
\text { excretion, } \\
\text { Bone mineral } \\
\text { content } \\
\text { (BMC) } \\
\text { IGF-I }\end{array}$ & $\begin{array}{l}\text { Eucaloric diets } \\
\text { Low protein } \\
\text { (LP) diet } \\
\text { versus } \\
\text { High protein } \\
\text { (HP) diet } \\
\text { Meat exchanged } \\
\text { isocaloric for } \\
\text { carbohydrates }\end{array}$ & & $\begin{array}{l}\text { FFQ self- } \\
\text { administered } \\
\text { on site and } \\
\text { reviewed for } \\
\text { completeness } \\
\text { by a dietician. } \\
\text { Information } \\
\text { about } \\
\text { validation } \\
\text { only as } \\
\text { several } \\
\text { references }\end{array}$ & $\begin{array}{l}16 \mathrm{LP}(71.8 \pm \\
9.8 \mathrm{y}) \\
16 \mathrm{HP}(64.6 \pm \\
10.8 \mathrm{y})\end{array}$ & $\begin{array}{l}\text { LP diet: } 16 \pm 3 \\
\text { E\% protein. } \\
\text { Food } \\
\text { supplement with } \\
2.87 \text { g protein } \\
\text { HP diet: } 24 \pm 8 \\
\text { E\% protein. } \\
\text { Food } \\
\text { supplement with } \\
57.6 \text { g protein }\end{array}$ & 63 days & $\begin{array}{l}\text { Weight stability. } \\
\text { No difference in } \\
\text { urinary calcium } \\
\text { excretion. The } \\
\text { HP group had } \\
\text { increased BMC } \\
\text { over } 9 \text { weeks } \\
\text { ( } P=0.049 \text { ) but } \\
\text { not in LP group } \\
\text { IGF-I increased } \\
\text { in HP group } \\
(\mathrm{P}=0.008)\end{array}$ & & $\begin{array}{l}\text { C } \\
\text { Underreported } \\
\text { usual diet and } \\
\text { in the HP } \\
\text { group } \\
(\approx .6 \mathrm{MJ}) . \\
\text { Thus we do } \\
\text { not know the } \\
\text { actual protein } \\
\text { intake. }\end{array}$ \\
\hline $\begin{array}{l}\text { Devine } \\
\text { et al., } \\
2005 \\
\text { (16) } \\
\text { Australia }\end{array}$ & $\begin{array}{l}\text { Prospective } \\
\text { cohort }\end{array}$ & $\begin{array}{l}\text { Originally a } \\
5 \text {-y trial of } \\
\text { calcium } \\
\text { supplementa- } \\
\text { tion and } \\
\text { fracture }\end{array}$ & $\begin{array}{l}\text { BMD at the } \\
\text { hip after } \\
\text { I year }\end{array}$ & $\begin{array}{l}\text { Total protein } \\
\text { intake in g/day } \\
\text { and in } \mathrm{E} \% \\
\text { expressed in } \\
\text { tertiles }\end{array}$ & & $\begin{array}{l}\text { FFQ } \\
\text { (developed by } \\
\text { Anti Cancer } \\
\text { Council of } \\
\text { Victoria). } \\
\text { Information }\end{array}$ & I,077 women & $\begin{array}{l}\text { Mean total } \\
\text { protein intake } \\
1.2 \mathrm{~g} / \mathrm{kg} \mathrm{BW} \text { or } \\
19 \mathrm{E} \% \\
\mathrm{TI}:<66 \mathrm{~g} / \mathrm{d} \\
\mathrm{T} 3:>87 \mathrm{~g} / \mathrm{d}\end{array}$ & I y & $\begin{array}{l}\text { Protein intake } \\
\text { associated to } \\
\text { BMD: } r=0.138 \\
(\mathrm{P}<0.00 \mathrm{I}) \\
\text { Lowest } \\
\text { tertile }\end{array}$ & $\begin{array}{l}\text { Age, BMI, } \\
\text { calcium } \\
\text { treatment }\end{array}$ & $\begin{array}{l}\text { B } \\
\text { Only one year } \\
\text { follow-up and } \\
\text { no baseline } \\
\text { measurement } \\
\text { of BMD. Only }\end{array}$ \\
\hline
\end{tabular}


Appendix 4 (Continued)

\begin{tabular}{|c|c|c|c|c|c|c|c|c|c|c|c|c|}
\hline Reference & $\begin{array}{l}\text { Study } \\
\text { design }\end{array}$ & Population & $\begin{array}{l}\text { Outcome } \\
\text { measures }\end{array}$ & $\begin{array}{l}\text { Intervention/ } \\
\text { exposure }\end{array}$ & $\begin{array}{l}\text { Time between } \\
\text { baseline } \\
\text { exposure and } \\
\text { outcome } \\
\text { assessment }\end{array}$ & $\begin{array}{l}\text { Dietary } \\
\text { assessment } \\
\text { method }\end{array}$ & $\begin{array}{c}\text { No of } \\
\text { subjects } \\
\text { analysed }\end{array}$ & Intervention & $\begin{array}{l}\text { Follow-up } \\
\text { period, } \\
\text { drop-out } \\
\text { rate }\end{array}$ & Results & $\begin{array}{l}\text { Confounders } \\
\text { adjusted for }\end{array}$ & $\begin{array}{l}\text { Study quality } \\
\text { and relevance, } \\
\text { Comments } \\
\text { A-C }\end{array}$ \\
\hline $\begin{array}{l}\text { Hannan } \\
\text { et al., } \\
2000 \text { (19) } \\
\text { USA }\end{array}$ & $\begin{array}{l}\text { Prospective } \\
\text { cohort }\end{array}$ & $\begin{array}{l}\text { outcome. } \\
\text { I } 8 \% \text { response } \\
\text { rate and I/3 } \\
\text { were included } \\
\text { in the present } \\
\text { study. } \\
N=1,077 \\
\text { women and } \\
\text { age } 75 \pm 3 \text { y at } \\
\text { baseline }\end{array}$ & $\begin{array}{l}\text { BMD in } \\
\text { femur, radial } \\
\text { shaft and } \\
\text { spine } \\
\text { and the } \\
4-y e a r \text { losses }\end{array}$ & $\begin{array}{l}\text { Total, animal and } \\
\text { vegetable } \\
\text { protein intake } \\
\text { expressed as E\% } \\
\text { and in quartiles }\end{array}$ & & $\begin{array}{l}\text { I26-item FFQ } \\
\text { (Willett) over } \\
\text { the past year. } \\
\text { Evaluation } \\
\text { found minor } \\
\text { 2-y changes in } \\
\text { ranking } \\
\text { (quartiles) of } \\
\text { protein } \\
\text { Exclusion of } \\
\text { implausible } \\
\text { energy in- } \\
\text { takes (< } 600 \\
\text { kcal and > } \\
4000 \mathrm{kcal} \text { ) }\end{array}$ & $\begin{array}{l}615 \text { (64\% } \\
\text { women) }\end{array}$ & $\begin{array}{l}\text { Mean total } \\
\text { protein intake I6 } \\
\text { E\% (7-30 E\%) } \\
\text { Animal protein } \\
\text { intake } 10 \mathrm{E} \% \\
\text { Q I: } 7.3-13.5 \mathrm{E} \% \\
(0.21-0.71 \mathrm{~g} / \mathrm{kg} \\
\mathrm{BW}) \\
\mathrm{Q} 4: 17.9-27.4 \\
\mathrm{E} \%(\mathrm{I} .24-2.78 \mathrm{~g} / \\
\mathrm{kg} \mathrm{BW})\end{array}$ & $\begin{array}{l}4 \text { y } \\
28 \% \\
\text { follow-up } \\
\text { loss }\end{array}$ & $\begin{array}{l}\text { compared to } \\
\text { highest } \\
\text { Significant lower } \\
\text { BMD ( } \mathrm{P}<0.05 \text { ) } \\
\text { Lowest } \\
\text { compared to } \\
\text { the two highest } \\
\text { tertiles ( } \geq 66 \mathrm{~g} / \\
\text { day) was } \\
\text { associated with } \\
2.5-3 \% \text { lower } \\
\text { hip BMD } \\
\text { Total and animal } \\
\text { protein E\% } \\
\text { inversely related } \\
\text { to bone loss at } \\
\text { femur and spine. } \\
\text { Compared to } \\
\text { highest quartile } \\
\text { the lowest } \\
\text { quartile of } \\
\text { protein was } \\
\text { related to bone } \\
\text { loss at femoral } \\
\text { neck ( } \mathrm{P}=0.02 \text { ) } \\
\text { and spine } \\
\text { ( } \mathrm{P}=0.02 \text { ) } \\
\text { and also } \\
\text { significant for } \\
\text { animal protein }\end{array}$ & $\begin{array}{l}\text { Age, sex, } \\
\text { weight, } \\
\text { height, weight } \\
\text { change, } \\
\text { energy intake, } \\
\text { smoking, } \\
\text { alcohol, } \\
\text { caffeine, } \\
\text { physical } \\
\text { activity, } \\
\text { calcium intake } \\
\text { incl. } \\
\text { supplement } \\
\text { and hormone } \\
\text { use }\end{array}$ & $\begin{array}{l}\text { limited } \\
\text { information } \\
\text { about the } \\
\text { dietary } \\
\text { assessment } \\
\text { method. } \\
\text { A total protein } \\
\text { intake of } \\
>66 \mathrm{~g} / \text { day } \\
(0.84 \mathrm{~g} / \mathrm{kg} \mathrm{BW}) \\
\text { was associated } \\
\text { with higher } \\
\text { BMD } \\
\text { B }\end{array}$ \\
\hline
\end{tabular}




\begin{tabular}{|c|c|c|c|c|c|c|c|c|c|c|c|c|}
\hline Reference & $\begin{array}{l}\text { Study } \\
\text { design }\end{array}$ & Population & $\begin{array}{l}\text { Outcome } \\
\text { measures }\end{array}$ & $\begin{array}{l}\text { Intervention/ } \\
\text { exposure }\end{array}$ & $\begin{array}{l}\text { Time between } \\
\text { baseline } \\
\text { exposure and } \\
\text { outcome } \\
\text { assessment }\end{array}$ & $\begin{array}{l}\text { Dietary } \\
\text { assessment } \\
\text { method }\end{array}$ & $\begin{array}{l}\text { No of } \\
\text { subjects } \\
\text { analysed }\end{array}$ & Intervention & $\begin{array}{l}\text { Follow-up } \\
\text { period, } \\
\text { drop-out } \\
\text { rate }\end{array}$ & Results & $\begin{array}{l}\text { Confounders } \\
\text { adjusted for }\end{array}$ & $\begin{array}{l}\text { Study quality } \\
\text { and relevance, } \\
\text { Comments } \\
\text { A-C }\end{array}$ \\
\hline $\begin{array}{l}\text { Meng et al., } \\
2009 \\
(14) \\
\text { Australia }\end{array}$ & $\begin{array}{l}\text { Prospective } \\
\text { cohort }\end{array}$ & $\begin{array}{l}\text { I, } 169 \text { out of } \\
\text { I,500 com- } \\
\text { munity- } \\
\text { dwelling } \\
\text { women } \\
(70-85 \text { y) did } \\
5 \text { years } \\
\text { follow-up and } \\
\text { of these } 906 \\
\text { had a whole } \\
\text { body DXA }\end{array}$ & BMC & $\begin{array}{l}\text { Tertiles of } \\
\text { protein intake in } \\
\text { g/day }\end{array}$ & & $\begin{array}{l}\text { FFQ } \\
\text { Over the last } \\
\text { I2-month } \\
\text { period. } \\
\text { Information } \\
\text { about } \\
\text { validation } \\
\text { only as } \\
\text { several } \\
\text { references }\end{array}$ & $\begin{array}{l}862 \text { women, } \\
75 \pm 3 \text { y }\end{array}$ & $\begin{array}{l}\text { Mean protein } \\
\text { intake } 1.2 \mathrm{~g} / \mathrm{kg} \\
\mathrm{BW} / \mathrm{d} \text { or } 19 \mathrm{E} \% \\
\mathrm{TI}: 0.84 \mathrm{~g} / \mathrm{kg} \\
\mathrm{BW} \text { or } 18 \mathrm{E} \% \\
\mathrm{~T} 3:>1.6 \mathrm{~g} / \mathrm{kg} \\
\mathrm{BW} \text { or } 20 \mathrm{E} \%\end{array}$ & 5 year & $\begin{array}{l}\text { Top tertile } \\
\text { protein intake } \\
\text { vs. lowest tertile } \\
\text { had a 5\% } \\
\text { higher whole } \\
\text { body BMC }\end{array}$ & $\begin{array}{l}\text { Age, height, } \\
\text { energy intake, } \\
\text { physical } \\
\text { activity, } \\
\text { calcium } \\
\text { treatment }\end{array}$ & $\begin{array}{l}\text { C } \\
\text { Part of a } \\
\text { prospective } \\
\text { randomized } \\
\text { controlled } \\
\text { cohort trial of } \\
\text { supplemental } \\
\text { calcium to } \\
\text { prevent } \\
\text { fractures. } \\
\text { No DXA at } \\
\text { start. } \\
\text { Underreporting } \\
\text { in lowest } \\
\text { tertile of } \\
\text { protein intake } \\
\text { (energy } \\
\text { intake } \approx 5.3 \mathrm{MJ} \text { ) }\end{array}$ \\
\hline $\begin{array}{l}\text { Misra et al., } \\
2011 \\
(22) \\
\text { USA }\end{array}$ & $\begin{array}{l}\text { Prospective } \\
\text { cohort }\end{array}$ & $\begin{array}{l}\text { Framingham } \\
\text { Osteoporosis } \\
\text { Study } \\
946 \text { men and } \\
\text { women in } \\
\text { 1988-89, } \\
\text { mean age ca. } \\
75 \text { y }\end{array}$ & $\begin{array}{l}\text { Self-reported } \\
\text { fracture of } \\
\text { proximal } \\
\text { femur } \\
\text { confirmed by } \\
\text { medical } \\
\text { records. } \\
\text { Incidence } \\
\text { rates per } \\
\text { I000 } \\
\text { persons-years }\end{array}$ & $\begin{array}{l}\text { Total protein } \\
\text { intake } \\
\text { expressed as } \\
\text { energy adjusted } \\
\text { g/day and in } \\
\text { quartiles }\end{array}$ & & $\begin{array}{l}\text { I26-item FFQ } \\
\text { over the past } \\
\text { year. } \\
\text { Evaluation } \\
\text { found minor } \\
\text { 2-y changes in } \\
\text { ranking } \\
\text { (quartiles) of } \\
\text { protein } \\
\text { (according to } \\
\text { ref. 19). } \\
\text { Exclusion of } \\
\text { implausible } \\
\text { energy } \\
\text { intakes }\end{array}$ & $\begin{array}{l}946(61 \% \\
\text { women) and } \\
100 \text { fractures }\end{array}$ & $\begin{array}{l}\text { Mean intake } \\
\text { app } 68 \mathrm{~g} / \text { day } \\
\text { (ca I.I g/kg BW) } \\
\text { QI: } 46.5 \pm 7 \mathrm{~g} / \\
\text { day } \\
\text { Q2-4: up to } \\
82.7 \pm 10 \mathrm{~g} / \text { day }\end{array}$ & $\begin{array}{l}11.6 \\
\text { person } \\
\text { years }\end{array}$ & $\begin{array}{l}\text { The upper } \\
\text { three quartiles } \\
\text { compared to } \\
\text { lowest quartile: } \\
\text { HR } 0.63 \text { ( } 95 \% \\
\mathrm{Cl}: 0.4 \mathrm{I}-0.97 \text { ) }\end{array}$ & $\begin{array}{l}\text { Age, sex, } \\
\text { height, BW, } \\
\text { energy intake }\end{array}$ & B \\
\hline
\end{tabular}


Appendix 4 (Continued)

\begin{tabular}{|c|c|c|c|c|c|c|c|c|c|c|c|c|}
\hline Reference & $\begin{array}{l}\text { Study } \\
\text { design }\end{array}$ & Population & $\begin{array}{l}\text { Outcome } \\
\text { measures }\end{array}$ & $\begin{array}{l}\text { Intervention/ } \\
\text { exposure }\end{array}$ & $\begin{array}{l}\text { Time between } \\
\text { baseline } \\
\text { exposure and } \\
\text { outcome } \\
\text { assessment }\end{array}$ & $\begin{array}{l}\text { Dietary } \\
\text { assessment } \\
\text { method }\end{array}$ & $\begin{array}{c}\text { No of } \\
\text { subjects } \\
\text { analysed }\end{array}$ & Intervention & $\begin{array}{l}\text { Follow-up } \\
\text { period, } \\
\text { drop-out } \\
\text { rate }\end{array}$ & Results & $\begin{array}{l}\text { Confounders } \\
\text { adjusted for }\end{array}$ & $\begin{array}{c}\text { Study quality } \\
\text { and relevance, } \\
\text { Comments } \\
\text { A-C }\end{array}$ \\
\hline & & & & & & $\begin{array}{l}(<600 \mathrm{kcal} \\
\text { and }>4000 \\
\text { kcal })\end{array}$ & & & & & & \\
\hline $\begin{array}{l}\text { Promislow } \\
\text { et al., } \\
2002 \text { (17) } \\
\text { USA }\end{array}$ & $\begin{array}{l}\text { Prospective } \\
\text { cohort }\end{array}$ & $\begin{array}{l}\text { The Rancho } \\
\text { Bernardo } \\
\text { Study } \\
\text { I526 (58\% } \\
\text { women) } \\
\text { community- } \\
\text { dwelling } \\
55-92 \text { y in } \\
\text { 1988-1992 }\end{array}$ & $\begin{array}{l}\text { Total BMD } \\
\text { and at hip, } \\
\text { femur, and } \\
\text { spine at } \\
\text { baseline } \\
\text { And after } \\
4 \text { years } \\
\text { rate of bone } \\
\text { loss/y }\end{array}$ & $\begin{array}{l}\text { Total, animal and } \\
\text { vegetable } \\
\text { protein intake } \\
\text { Energy adjusted } \\
\text { in g/day }\end{array}$ & & $\begin{array}{l}\text { I28-item } \\
\text { FFQ } \\
\text { (Harvard- } \\
\text { Willet). } \\
\text { Information } \\
\text { about } \\
\text { validation } \\
\text { only as a } \\
\text { reference }\end{array}$ & $\begin{array}{l}572(65 \%) \\
\text { females and } \\
388(60 \%) \\
\text { males }\end{array}$ & $\begin{array}{l}\text { Mean intake ca. } \\
72 \mathrm{~g} / \text { day } \\
\text { Animal protein } \\
\text { intake ca. } 2 / 3 \text { of } \\
\text { total intake }\end{array}$ & 4 year & $\begin{array}{l}\text { For women, } \\
\text { animal protein } \\
\text { intake was } \\
\text { positively } \\
\text { associated and } \\
\text { vegetable protein } \\
\text { intake inversely } \\
\text { associated with } \\
\text { 4-y total BMD } \\
\text { at hip femoral } \\
\text { neck For men, } \\
\text { vegetable } \\
\text { protein intake } \\
\text { was inversely } \\
\text { associated to } \\
\text { total body BMD } \\
\text { and at hip and } \\
\text { spine. } \\
\text { NS association } \\
\text { between protein } \\
\text { intake and rate/y } \\
\text { of bone loss. }\end{array}$ & $\begin{array}{l}\text { Age, BMI, } \\
\text { change in } \\
\text { body weight, } \\
\text { calcium intake } \\
\text { incl. suppl., } \\
\text { diabetes } \\
\text { status, years } \\
\text { of postmeno- } \\
\text { pause, } \\
\text { physical } \\
\text { activity, } \\
\text { smoking, } \\
\text { alcohol, } \\
\text { hormones } \\
\text { intake }\end{array}$ & B \\
\hline $\begin{array}{l}\text { Rapuri et al. } \\
2003(20) \\
\text { USA }\end{array}$ & $\begin{array}{l}\text { Prospective } \\
\text { cohort } \\
\text { The cross- } \\
\text { sectional } \\
\text { analyses at } \\
\text { baseline } \\
\text { not } \\
\text { included }\end{array}$ & $\begin{array}{l}489 \text { women } \\
\text { aged } 65-77 \text { y } \\
\text { enrolled in an } \\
\text { osteoporosis } \\
\text { intervention } \\
\text { study (the } \\
\text { STOP IT } \\
\text { trial). }\end{array}$ & $\begin{array}{l}\text { BMD at } \\
\text { baseline } \\
\text { (cross- } \\
\text { sectional } \\
\text { data) and } \\
\text { bone loss } \\
\text { after } 3 y\end{array}$ & $\begin{array}{l}\text { Quartiles of } \\
\text { protein intake in } \\
\mathrm{E} \%\end{array}$ & & $\begin{array}{l}\text { 7-d food } \\
\text { diaries. No } \\
\text { information } \\
\text { about } \\
\text { validation }\end{array}$ & 92 women & $\begin{array}{l}\text { Lowest quartile } \\
\text { of total protein } \\
\text { intake } \approx 13 \mathrm{E} \% \\
\text { Highest } \\
\text { quartile } \approx 20 \mathrm{E} \%\end{array}$ & $3 y$ & $\begin{array}{l}\text { NS association } \\
\text { to } 3 \text {-y-bone loss }\end{array}$ & $\begin{array}{l}\text { Age, BMI, } \\
\text { intakes of } \\
\text { calcium, } \\
\text { caffeine, fiber } \\
\text { and vitamin D, } \\
\text { smoking } \\
\text { status and } \\
\text { alcohol use }\end{array}$ & $\begin{array}{l}\text { C } \\
\text { Underreported } \\
\text { baseline diet } \\
\text { (ca. } 6 \mathrm{MJ} \text { ). } \\
\text { Thus we do } \\
\text { not know the } \\
\text { actual protein } \\
\text { intake }\end{array}$ \\
\hline
\end{tabular}




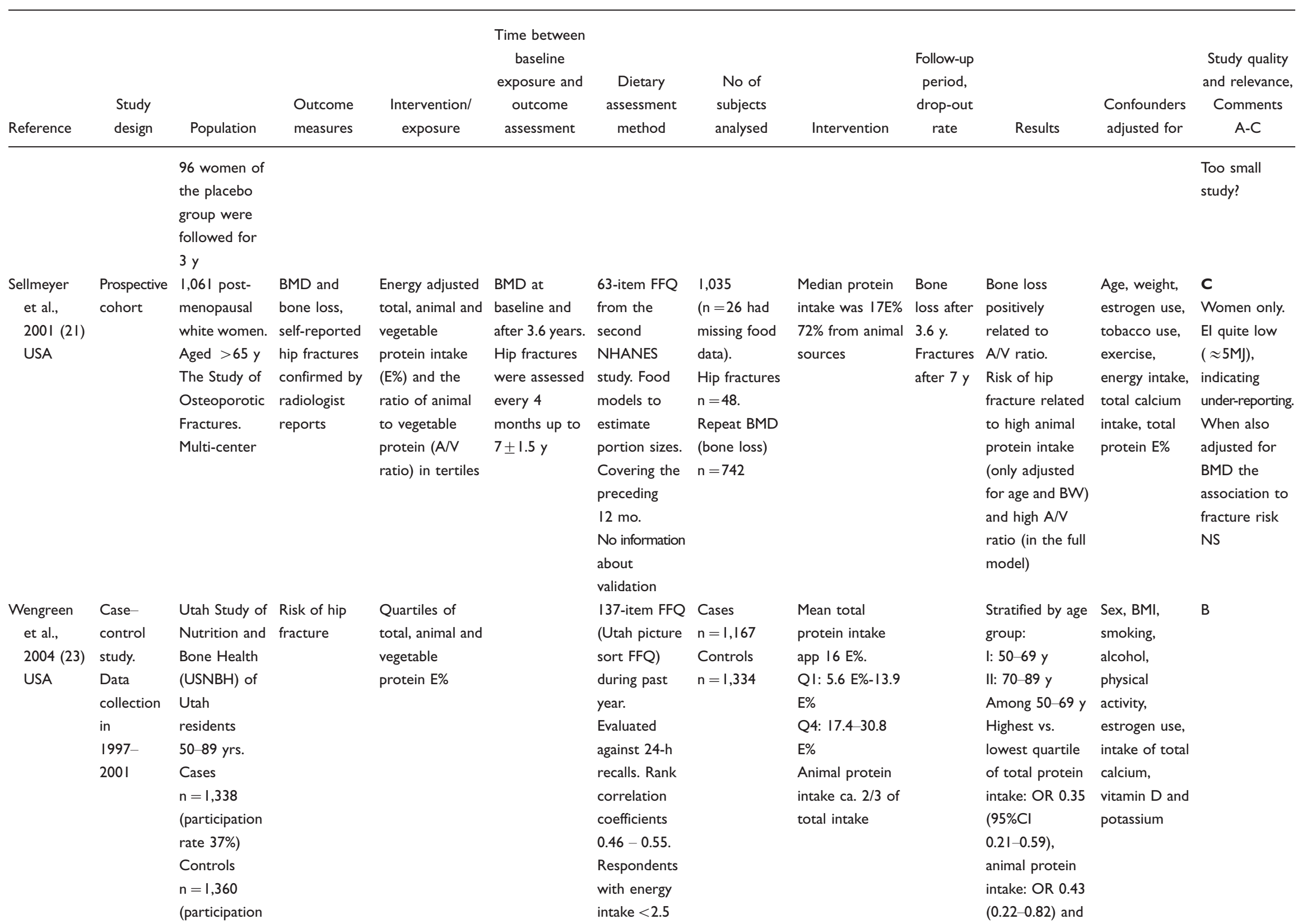


Appendix 4 (Continued)

\begin{tabular}{|c|c|c|c|c|c|c|c|c|c|c|c|c|}
\hline Reference & $\begin{array}{l}\text { Study } \\
\text { design }\end{array}$ & Population & $\begin{array}{l}\text { Outcome } \\
\text { measures }\end{array}$ & $\begin{array}{l}\text { Intervention/ } \\
\text { exposure }\end{array}$ & $\begin{array}{l}\text { Time between } \\
\text { baseline } \\
\text { exposure and } \\
\text { outcome } \\
\text { assessment }\end{array}$ & $\begin{array}{c}\text { Dietary } \\
\text { assessment } \\
\text { method }\end{array}$ & $\begin{array}{c}\text { No of } \\
\text { subjects } \\
\text { analysed }\end{array}$ & Intervention & $\begin{array}{l}\text { Follow-up } \\
\text { period, } \\
\text { drop-out } \\
\text { rate }\end{array}$ & Results & $\begin{array}{l}\text { Confounders } \\
\text { adjusted for }\end{array}$ & $\begin{array}{l}\text { Study quality } \\
\text { and relevance, } \\
\text { Comments } \\
\text { A-C }\end{array}$ \\
\hline $\begin{array}{l}\text { Zoltick } \\
\text { et al., } \\
2011 \\
(24) \\
\text { USA }\end{array}$ & $\begin{array}{l}\text { Prospective } \\
\text { cohort }\end{array}$ & $\begin{array}{l}\text { Framingham } \\
\text { Original } \\
\text { Cohort study, } \\
\mathrm{n}=1,402 \text { at } \\
\text { baseline in } \\
\text { 1988-1989. } \\
\text { (Originally } \\
5,209 \text { free- } \\
\text { living men and } \\
\text { women), } \\
\text { residents in } \\
\text { nursing } \\
\text { homes } \\
\text { excluded }\end{array}$ & $\begin{array}{l}\text { Self-reported } \\
\text { falls during } \\
\text { last year, at } \\
\text { baseline and } \\
\text { at } 12 \text { months } \\
\text { follow-up }\end{array}$ & $\begin{array}{l}\text { Total, animal and } \\
\text { vegetable } \\
\text { protein } \\
\text { expressed as } \\
\text { g/day and as } \\
\text { energy adjusted } \\
\text { tertiles }\end{array}$ & $\begin{array}{l}\text { Baseline and } \\
\text { after } 12 \\
\text { months }\end{array}$ & $\begin{array}{l}\text { MJ or >20.9 } \\
\text { MJ were } \\
\text { excluded. El/ } \\
\text { BMR range } \\
\text { I.57 - I.89 } \\
\text { among men- } \\
\text { women and } \\
\text { case-controls } \\
\text { I26-item FFQ } \\
\text { (Willett) } \\
\text { Respondents } \\
\text { with energy } \\
\text { intake }< \\
600 \text { kcal or } \\
>4,000 \text { kcal } \\
\text { were } \\
\text { excluded. }\end{array}$ & $\begin{array}{l}807,63 \% \\
\text { women, mean } \\
\text { age } 75 \pm 4.8 \text { y }\end{array}$ & $\begin{array}{l}\text { Mean total } \\
\text { protein intake } \\
69 \mathrm{~g} / \text { day (ca. } \\
16 \mathrm{E} \% \text { ) } \\
\text { Animal protein } \\
\text { intake ca. } 2 / 3 \\
\text { of total intake }\end{array}$ & $\begin{array}{l}12 \\
\text { months }\end{array}$ & $\begin{array}{l}\text { vegetable } \\
\text { protein intake: } \\
\text { OR } 0.52 \\
(0.27-0.997) \\
\text { Among } 70-89 \text { y } \\
\text { NS associations }\end{array}$ & $\begin{array}{l}\text { Age, sex, } \\
\text { height, BW, } \\
\text { energy intake, } \\
\text { baseline falls, } \\
\text { animal and } \\
\text { plant protein } \\
\text { intake } \\
\text { adjusted for } \\
\text { each other } \\
\text { when } \\
\text { examined }\end{array}$ & $\begin{array}{l}\text { C } \\
\text { Very limited } \\
\text { information } \\
\text { about the } \\
\text { dietary intake } \\
\text { assessment }\end{array}$ \\
\hline
\end{tabular}




\section{Appendix 4. Evidence tables}

Table 4. Evidence table: protein and physical training

\begin{tabular}{|c|c|c|c|c|c|c|c|c|c|c|c|c|}
\hline Reference & $\begin{array}{l}\text { Study } \\
\text { design }\end{array}$ & Population & $\begin{array}{l}\text { Outcome } \\
\text { measures }\end{array}$ & $\begin{array}{l}\text { Intervention/ } \\
\text { exposure }\end{array}$ & $\begin{array}{l}\text { Time between } \\
\text { baseline } \\
\text { exposure and } \\
\text { outcome } \\
\text { assessment }\end{array}$ & $\begin{array}{c}\text { Dietary } \\
\text { assessment } \\
\text { method }\end{array}$ & $\begin{array}{l}\text { No. of } \\
\text { subjects } \\
\text { analysed }\end{array}$ & Intervention & $\begin{array}{c}\text { Follow-up } \\
\text { period, } \\
\text { drop-out rate }\end{array}$ & Results & $\begin{array}{l}\text { Confounders } \\
\text { adjusted for }\end{array}$ & $\begin{array}{c}\text { Study quality } \\
\text { and relevance, } \\
\text { Comments } \\
\text { A-C }\end{array}$ \\
\hline $\begin{array}{l}\text { Campbell } \\
\text { et al., } \\
2002 \\
(25) \\
\text { USA }\end{array}$ & $\mathrm{RCT}$ & $\begin{array}{l}29 \text { healthy } \\
\text { men (12) and } \\
\text { women (17), } \\
55-78 \text { y }\end{array}$ & $\begin{array}{l}\text { Body } \\
\text { composition } \\
\text { (deuterium } \\
\text { dilution), } \\
\text { muscle area: } \\
\text { mid-thigh and } \\
\text { mid-arm } \\
\text { (CT), } \\
\text { Strength, } \\
\text { N-balance }\end{array}$ & $\begin{array}{l}\text { Resistive } \\
\text { training (RT) of } \\
\text { lower body vs. } \\
\text { whole body vs. } \\
\text { sedentary. All } \\
\text { received } 0.8 \mathrm{~g} \\
\text { protein/kg BW/ } \\
\mathrm{d} \text { in euenergetic } \\
\text { (weight- } \\
\text { maintaining) } \\
\text { menus }\end{array}$ & I4 week & $\begin{array}{l}\text { Participants } \\
\text { were } \\
\text { provided food }\end{array}$ & & & & $\begin{array}{l}\text { Body water and } \\
\text { fat-free mass } \\
\text { decreased and } \\
\text { relative fat mass } \\
\text { increased in } \\
\text { general. Mid-thigh } \\
\text { muscle area } \\
\text { increased with RT, } \\
\text { and decreased with } \\
\text { sedentarism. It is } \\
\text { concluded that } \\
\text { with RT the body } \\
\text { adapts to } 0.8 \mathrm{~g} \text {, } \\
\text { whereas muscle } \\
\text { mass was lost in } \\
\text { the sedentary }\end{array}$ & & $\begin{array}{l}\text { B } \\
\text { Small study, } 0.8 \\
\text { g protein/kg } \\
\text { BW/d appears } \\
\text { to be a } \\
\text { minimum for } \\
\text { adaptation with } \\
\text { RT in healthy, } \\
\text { but maybe } \\
\text { inadequate } \\
\text { for sedentary } \\
\text { subjects }\end{array}$ \\
\hline $\begin{array}{l}\text { Haub } \\
\text { et al., } \\
2002 \\
(26) \\
\text { USA }\end{array}$ & RCT & $\begin{array}{l}26 \text { healthy } \\
\text { men }\end{array}$ & $\begin{array}{l}\text { Body } \\
\text { composition, } \\
\text { muscle } \\
\text { cross- } \\
\text { sectional area, } \\
\text { muscle } \\
\text { strength }\end{array}$ & $\begin{array}{l}\text { Euenergetic } \\
\text { diets } \\
\text { supplemented } \\
\text { with } 0.6 \mathrm{~g} / \mathrm{kg} \\
\mathrm{BW} \text { beef vs. } 0.6 \\
\mathrm{~g} / \mathrm{kg} \mathrm{BW} \text { soy } \\
\text { protein in } \\
\text { combination } \\
\text { with resistance } \\
\text { training }\end{array}$ & I2 week & $\begin{array}{l}\text { Food records } \\
\text { for } 3 \text { days, } \\
\text { week I } \\
\text { (habitual), } \\
\text { w2 start of } \\
\text { intervention, } \\
\text { week } 15 \text { end } \\
\text { of study }\end{array}$ & $\begin{array}{l}2 I, 65 \pm 5 y \\
\text { BMI } 28\end{array}$ & $\begin{array}{l}\text { Mean protein } \\
\text { intake I-I.I7 } \\
\text { g/kg BW. } \\
\text { The beef gr. } \\
\text { consumed } \\
57 \% \text { of } \\
\text { protein from } \\
\text { beef, the soy } \\
\text { gr. consumed } \\
53 \% \text { from soy }\end{array}$ & $\begin{array}{l}3 \text { withdrew } \\
\text { I had a viral } \\
\text { infection, I } \\
\text { was iron } \\
\text { deficient }\end{array}$ & $\begin{array}{l}\text { Similar increases in } \\
\text { lean mass, muscle } \\
\text { cross-sectional } \\
\text { area, and muscle } \\
\text { strength }\end{array}$ & & $\begin{array}{l}\text { B } \\
\text { Small study, } \\
\text { protein intake } \\
\text { was adequate } \\
\text { from the } \\
\text { beginning }\end{array}$ \\
\hline
\end{tabular}


Appendix 4. Evidence tables

Table 5. Evidence table: protein and various outcomes

\begin{tabular}{|c|c|c|c|c|c|c|c|c|c|c|c|}
\hline Reference & Study design & Population & $\begin{array}{l}\text { Outcome } \\
\text { measures }\end{array}$ & $\begin{array}{l}\text { Intervention/ } \\
\text { exposure }\end{array}$ & $\begin{array}{c}\text { Dietary assessment } \\
\text { method }\end{array}$ & $\begin{array}{c}\text { No of } \\
\text { subjects } \\
\text { analysed }\end{array}$ & Intervention & $\begin{array}{c}\text { Follow-up } \\
\text { period, } \\
\text { drop-out rate }\end{array}$ & Results & $\begin{array}{l}\text { Confounders } \\
\text { adjusted for }\end{array}$ & $\begin{array}{c}\text { Study quality } \\
\text { and relevance, } \\
\text { Comments } \\
\text { A-C }\end{array}$ \\
\hline $\begin{array}{l}\text { Altorf-van } \\
\text { der Kuil } \\
\text { et al., } 2010 \\
\text { (27) } \\
\text { The } \\
\text { Netherlands }\end{array}$ & $\begin{array}{l}\text { Prospective } \\
\text { cohort }\end{array}$ & $\begin{array}{l}\text { The } \\
\text { Rotterdam } \\
\text { study, 7,983 } \\
(78 \%) \text { men } \\
\text { and women at } \\
\text { baseline, >55 } \\
\text { y Participants } \\
\text { with baseline } \\
\text { hypertension } \\
\text { (55\%) } \\
\text { excluded }\end{array}$ & $\begin{array}{l}\text { Hypertension } \\
\text { (SBP } \geq 140 \\
\mathrm{mmHg} \text { and } \\
\mathrm{DBP} \geq 90 \\
\mathrm{~mm} \mathrm{Hg} \text { ) or } \\
\text { use of antihy- } \\
\text { pertensive } \\
\text { medication }\end{array}$ & $\begin{array}{l}\text { Energy } \\
\text { adjusted total, } \\
\text { animal and } \\
\text { vegetable } \\
\text { protein intake } \\
\text { in g/day }\end{array}$ & $\begin{array}{l}\text { A checklist about } \\
\text { foods consumed at } \\
\text { least twice a month } \\
\text { during the preceding } \\
\text { year followed by a } \\
\text { I70-item interviewer } \\
\text { administrated FFQ. } \\
\text { Calibrated against } \\
\text { fifteen } 24 \text {-h food } \\
\text { records and four } 24 \text {-h } \\
\text { urinary urea excretions. } \\
\text { Correlations for total } \\
\text { protein intake } 0.66 \text { and } \\
0.59 \text { for vegetable } \\
\text { protein intake }\end{array}$ & $\begin{array}{l}2,24 \mathrm{I}(65 \pm 7 \\
y r), 43 \% \text { men. } \\
\mathrm{I}, \mathrm{I} \mathrm{I} 3 \text { cases }\end{array}$ & $\begin{array}{l}\text { Energy } \\
\text { adjusted } \\
\text { tertiles of } \\
\text { total protein } \\
\text { in g/day intake } \\
\text { were: } \\
\text { TI:70 } \pm 15 \\
(14 \mathrm{E} \%) \\
\text { T2: } 81 \pm 14 \\
\text { (17 E\%) } \\
\text { T3: } 97 \pm 19 \\
\text { (19 E\%) }\end{array}$ & $6 y$ & $\begin{array}{l}\text { Non-significant } \\
\text { associations } \\
\text { between } \\
\text { hypertension } \\
\text { and total, animal } \\
\text { and vegetable } \\
\text { protein. } \\
\text { In participants } \\
\geq 70 \text { y increased } \\
\text { risk of animal } \\
\text { protein: hazard } \\
\text { ratiol.37, } 95 \% \\
\mathrm{Cl} 1.009-1.5 \mathrm{I}\end{array}$ & $\begin{array}{l}\text { Age, sex, BMI, } \\
\text { baseline SBP, } \\
\text { smoking, alcohol, } \\
\text { energy intake, } \\
\text { potassium, } \\
\text { sodium, calcium, } \\
\text { magnesium, fiber, } \\
\text { carbohydrates, } \\
\text { SFA, PUFA, }\end{array}$ & $\begin{array}{l}\text { B } \\
\text { No information } \\
\text { about sodium } \\
\text { intake }\end{array}$ \\
\hline $\begin{array}{l}\text { Beasley et al., } \\
2010 \text { (28) } \\
\text { USA }\end{array}$ & $\begin{array}{l}\text { Prospective } \\
\text { cohort }\end{array}$ & $\begin{array}{l}\text { The Women's } \\
\text { Health } \\
\text { Imitative } \\
\text { Observational } \\
\text { Study } \\
\text { (WHI-OS) } \\
24,4 \text { I7 } \\
\text { non-frail } \\
\text { women aged } \\
65-79 \text { y at } \\
\text { baseline }\end{array}$ & $\begin{array}{l}\text { Frailty score. } \\
\text { Criteria: } \\
\text { muscle } \\
\text { weakness/ } \\
\text { slowness, } \\
\text { poor } \\
\text { endurance/ } \\
\text { exhaustion, } \\
\text { low physical } \\
\text { activity, } \\
\text { unintentional } \\
\text { weight loss }\end{array}$ & $\begin{array}{l}\text { Calibrated } \\
\text { total, and } \\
\text { animal } \\
\text { protein intake } \\
\text { expressed as } \\
\text { E\%, and } g / k g \\
\text { BW and in } \\
\text { quintiles }\end{array}$ & $\begin{array}{l}\text { I22-item FFQ } \\
\text { Reported energy } \\
\text { intake }<600 \text { and }> \\
5,000 \text { kcal were } \\
\text { excluded. Calibration } \\
\text { study showed a } \\
\text { modest } \\
\text { underestimated } \\
\text { protein intake }\end{array}$ & $\begin{array}{l}24,4 \mid 7 \\
3,298 \text { frail } \\
(13.5 \%)\end{array}$ & & $3 y$ & $\begin{array}{l}\text { Protein intake } \\
\text { expressed as } \\
\text { uncalibrated, } \\
\text { calibrated and in } \\
\text { quintiles was } \\
\text { inversely asso- } \\
\text { ciated to frailty. } \\
\text { For every } 20 \% \\
\text { increase in E\% } \\
\text { calibrated } \\
\text { protein intake } \\
\text { the OR was } \\
0.77(95 \% \mathrm{Cl} \\
0.58-0.87)\end{array}$ & $\begin{array}{l}\text { Age, ethnicity, } \\
\text { BMI, income, } \\
\text { education, } \\
\text { current health } \\
\text { provider, } \\
\text { smoking, alcohol, } \\
\text { health status, } \\
\text { history of } \\
\text { comorbidity, } \\
\text { hormone use, } \\
\text { number of falls, } \\
\text { living alone, ADL, } \\
\text { depressive } \\
\text { symptoms, } \\
\text { calibrated energy } \\
\text { intake, fat E\%, } \\
\text { supplement use }\end{array}$ & B \\
\hline
\end{tabular}




\begin{tabular}{|c|c|c|c|c|c|c|c|c|c|c|c|}
\hline Reference & Study design & Population & $\begin{array}{l}\text { Outcome } \\
\text { measures }\end{array}$ & $\begin{array}{l}\text { Intervention/ } \\
\text { exposure }\end{array}$ & $\begin{array}{l}\text { Dietary assessment } \\
\text { method }\end{array}$ & $\begin{array}{c}\text { No of } \\
\text { subjects } \\
\text { analysed }\end{array}$ & Intervention & $\begin{array}{c}\text { Follow-up } \\
\text { period, } \\
\text { drop-out rate }\end{array}$ & Results & $\begin{array}{l}\text { Confounders } \\
\text { adjusted for }\end{array}$ & $\begin{array}{c}\text { Study quality } \\
\text { and relevance, } \\
\text { Comments } \\
\text { A-C }\end{array}$ \\
\hline \multirow{12}{*}{$\begin{array}{l}\text { Bates et al., } \\
2010 \\
(29) \\
\text { United } \\
\text { Kingdom }\end{array}$} & Prospective & The British & All-cause & Protein intake & 4-d weighed dietary & $\mathrm{I}, \mathrm{I} 00$ men & & $14 y$ & HR $0.86(95 \%$ & Only results for & C \\
\hline & cohort & National Diet & mortality & in $g / d$ & record. No further & and women & & & $\mathrm{Cl}: 0.77-0.97)$ & Age, sex, as & Under- \\
\hline & & and Nutrition & from the & & information about the & & & & & confounders are & reporting \\
\hline & & Survey of & National & & dietary assessment & & & & & shown & among women \\
\hline & & people Aged & Health & & method and its & & & & & & $(\mathrm{El}<6 \mathrm{MJ})$ \\
\hline & & 65 years and & Service & & validation & & & & & & Very limited \\
\hline & & Over & register & & & & & & & & information \\
\hline & & $\mathrm{I}, 100$ men & & & & & & & & & about study \\
\hline & & and women & & & & & & & & & methods. \\
\hline & & & & & & & & & & & Refers to a \\
\hline & & & & & & & & & & & report about \\
\hline & & & & & & & & & & & the study \\
\hline
\end{tabular}

